\title{
ACLARANDO TINTES DEMASIADO OSCUROS. LA ECONOMÍA ESPAÑOLA EN EL SIGLO XVIII
}

\author{
Clearing too dark dyes. The Spanish economy \\ in the 18 th century
}

\author{
Enrique LLOPIS y José Antonio SEBASTIÁN \\ Universidad Complutense de Madrid
}

Fecha de recepción: 6/07/2018

Fecha de aceptación definitiva: 2/03/2019

RESUMEN: Este trabajo evalúa la magnitud del crecimiento económico de España en el siglo XVIII y establece su distribución en el tiempo y en el espacio. Se sustenta en el estudio crítico de una extensa base factual de bautizados, difuntos y registros decimales, de numerosos materiales publicados y de una amplia bibliografía. Sostiene una visión de la economía española en el Setecientos, sobre todo en su segunda mitad, más positiva que la ofrecida tradicionalmente. Resalta, en ese sentido, la intensidad del crecimiento demográfico español en dicha centuria y su aceleración desde 1750; la simultaneidad del mismo, y del progreso económico asociado, en la mayor parte de las regiones peninsulares en la segunda mitad del siglo, y, en ese mismo período, el protagonismo del descenso de la mortalidad en el avance poblacional, la menor frecuencia e intensidad de las crisis demográficas, el aumento y diversificación de la producción agraria y el incremento aún más importante del producto no agrario.

Palabras clave: crecimiento económico; bautizados; mortalidad; diezmos; España; siglo XVIII.

ABSTRACT: This article provides a new estimate of economic growth and its pace and geographic distribution in $18^{\text {th }}$ century Spain. Grounded on an extensive database of baptism, burial and tithe records, published sources and bibliography, the article holds a more positive view of Spanish growth, particularly during the 
second half of the $18^{\text {th }}$ century, than the one traditionally held. Our research shows the intensity and acceleration of demographic growth after 1750 and its associated economic progress in most Spanish regions, the key role of decreasing mortality rates, the lower frequency and intensity of demographic crises, the increase and diversification of agricultural production, and the even larger increase of nonagricultural production.

Key words: economic growth; baptism and burial records; tithe records; Spain; eighteenth century.

\section{INTRODUCCIÓN ${ }^{1}$}

Los objetivos esenciales de este ensayo son dos: uno, evaluar la magnitud del crecimiento económico español en el siglo XVIII; y dos, realizar una aproximación a su distribución en el espacio y en el tiempo. Los datos y las valoraciones aquí empleados se sustentan en el examen crítico de diversas fuentes demográficas, sobre todo libros sacramentales y decimales; en la reconstrucción de numerosas series de bautizados y de difuntos; en la localización, tratamiento y análisis de registros de diezmos de calidad, poco utilizados ${ }^{2}$; en el amplio material factual publicado, y en la voluminosa literatura disponible sobre la España del Setecientos, de la que solo puede citarse una ínfima parte.

¿Cuál era la situación de la economía española hacia 1700? El interior aún estaba recobrándose de la profunda depresión que, desde finales del Quinientos, se había prolongado hasta mediados del Seiscientos o más allá. En su ámbito, el movimiento recesivo había sido intenso y duradero; el stock de capital y, por ende, la capacidad productiva de muchas economías campesinas había mermado, y, al menos en tierras de la Corona de Castilla, las formas de afrontar y distribuir las nuevas cargas fiscales habían dañado, en especial, a las actividades económicas urbanas y a la producción agraria mercantil. En ese contexto, la recuperación económica fue lenta, tortuosa y discontinua en el interior peninsular en la segunda mitad del siglo XVII ${ }^{3}$. En cambio, las regiones periféricas ya habían recobrado antes de 1700 los niveles demográficos y productivos máximos del inicio del

1. Este trabajo se ha financiado con el proyecto del Ministerio de Economía y Competitividad HAR2012-33810. Queremos agradecer a Leandro Prados y a Ricardo Hernández sus indicaciones bibliográficas, y a Vanesa Abarca su incansable trabajo y su compañerismo de archivo en archivo los últimos ocho años.

2. Véanse llopis, Bernardos y Velasco (2015); Abarca, Llopis, Sebastián, Bernardos y Velasco (2015); Abarca, llopis, Sánchez Salazar y Velasco (2016); Llopis, Sebastián, Abarca, Bernardos y Velasco (2016), y Llopis, Sebastián, Abarca, Sánchez Salazar y Velasco (2017), trabajos todos ellos financiados con los proyectos de investigación SEJ2005-05070/ECON, HAR2009-12436/HIST y HAR2012-33810.

3. Fortea (1980: 413-470); García SAnZ (1989); Marcos (2000: 454-551); Llopis (2010); SebasTIÁN (2013). 
Seiscientos, gracias a que la depresión fue en ellas menos intensa y duradera, y la recuperación posterior más briosa y continua. En Galicia y la cornisa cantábrica, esta última se sustentó en la transformación de los sistemas agrarios, siendo capital la difusión del maíz, grano que aportaba más calorías por unidad de superficie que los cereales tradicionales ${ }^{4}$. En Cataluña y Valencia, la recuperación económica del último tercio o cuarto del siglo XVII se desarrolló merced al amplio margen existente para efectuar roturaciones y al avance del viñedo y otros cultivos comerciales, de mayor valor añadido que los cereales y cuyas producciones se destinaban en parte a mercados foráneos ${ }^{5}$. En suma, hacia 1700, tanto el tipo como la magnitud y la solidez del crecimiento económico eran muy diversos en las distintas regiones españolas ${ }^{6}$. Y apenas iniciado el siglo XVIII, la Guerra de Sucesión y el agudo descenso térmico del final del decenio de 1700 supusieron una notable discontinuidad en la dinámica económica de cada una de ellas ${ }^{7}$.

En este artículo pretendemos demostrar, en la línea de lo apuntado por $\mathrm{Ardit}^{8}$ y por Ringrose 9 , que el crecimiento económico moderno arrancó en España en el Setecientos. Eso sí, en la mayor parte de regiones del interior el incremento del PIB por habitante, a nuestro juicio, no aconteció hasta la segunda mitad de dicha centuria.

Tras esta breve introducción, el artículo se estructura como sigue. En el epígrafe dos presentamos varias estimaciones recientes del crecimiento económico y agrario de diversos países europeos en la Edad Moderna, con especial atención a las trayectorias que trazan para el siglo XVIII. En el tres examinamos el desempeño de las principales variables demográficas; de los diezmos en ciertas regiones y en el conjunto de España, y del producto no agrario en el Setecientos, a fin de conocer mejor la distribución de su crecimiento económico en el espacio y en el tiempo y de testar algunas de las estimaciones efectuadas al respecto. En el cuatro, tratamos de explicar por qué los resultados demográficos y productivos mejoraron en nuestro país en la segunda mitad del siglo XVIII, especialmente en las regiones del interior peninsular. Y en el cinco, recogemos las principales conclusiones.

4. Fernández de Pinedo (1974: 24-28); Bilbao y Fernández de Pinedo (1984: 113-136); SaAVEDRA (1985: 167-180 y 1991: 229-240); ANES (1988: 34-56); LANZA (2010: 87-93).

5. Vilar (1978, tomo I: 425-452); VAlLS (2004: 49-76); ARDit (1993: 251-320).

6. Yun (1999).

7. Ruiz TORRES (2008: 75-76); Alberola (2009: 68-69).

8. $\operatorname{ARDIT}(2007: 9$ y 11).

9. «Existen pruebas considerables de que, como Francia, España experimentó un crecimiento económico lento, pero sostenido y acumulativo, desde finales del siglo XVII o inicios del XVIII. La tendencia varió de una región a otra y fue interrumpida por guerras, crisis de subsistencias y epidemias... A pesar de tales episodios, sin embargo, el país experimentó un crecimiento sostenido de su población y probablemente un incremento a largo plazo del producto nacional per cápita». RINGROSE (1996: 92-93). 


\section{UNOS NÚMEROS CADA VEZ MENOS LÚGUBRES}

Desde que Robert C. Allen publicó en 2000 su muy citado artículo ${ }^{10}$, y hasta hace pocos años, la mayoría de las estimaciones del crecimiento agrario en diversos países europeos en la Edad Moderna y la temprana Edad Contemporánea se llevaron a cabo por la vía de la demanda ${ }^{11}$. Según esta, se estima primero el consumo por habitante, mediante una función en la que los salarios de los trabajadores urbanos (como proxy de la renta por habitante), los precios de los productos agrarios y no agrarios y las elasticidades precio y renta de demanda constituyen las variables independientes. A continuación, los datos de población y el supuesto de que los saldos de las balanzas comerciales agrarias eran muy pequeños permiten transformar el consumo por habitante en cifras de producción agraria ${ }^{12}$.

La vía de la demanda arrojó inicialmente cifras que obligaban a valorar de modo bastante negativo el desempeño del sector primario en la Europa moderna. Según Allen, el producto agrario por habitante, entre 1500 y 1800, habría retrocedido un 34\% en Italia, un 33\% en Bélgica, un 32\% en Austria e Inglaterra, un 25\% en España, un 24\% en Alemania, un 22\% en Francia, un 10\% en Polonia y un $4 \%$ en Holanda ${ }^{13}$. Investigaciones efectuadas con más y mejores datos sobre países concretos ofrecieron también balances de la agricultura en los siglos modernos bastante adversos. Así, Federico y Malanima estimaron una caída del producto agrario por habitante en el centro y norte de Italia del 17,5\% entre $1490-1500$ y $1790-1800^{14}$; por su parte, Álvarez-Nogal y Prados calcularon una disminución de dicha variable en España del 44,2\% entre 1530 y $1787^{15}$. En suma, todas las primeras estimaciones mediante la vía de la demanda trazaron un cuadro desolador de la agricultura europea: entre comienzos del siglo XVI y finales del XVIII, el producto agrario habría crecido bastante menos que la población. Con tales resultados y dada la nítida hegemonía del sector primario en las economías de la época, no puede sorprender que las reconstrucciones del PIB de varios países europeos que incluían la estimación del producto agrario por la vía de la demanda ofreciesen un panorama bastante sombrío de su desempeño económico entre los albores del siglo XVI y los últimos compases del XVIII.

10. AlLEN (2000)

11. Véanse, sin ánimo de exhaustividad, Federico y Malanima (2004); Malanima (2003, 2006) y 2011); Pfister (2011); Álvarez-Nogal y Prados (2007 y 2013); SchÖn y Kranz (2012); Buyst (2011); Freire Costa, Palma y Reis (2014); Palma y Reis (2014 y 2016); Reis (2017).

12. AlLEN (2000: 13-18).

13. AlLEN (2000: 19).

14. Federico y Malanima (2004: 460).

15. Álvarez-Nogal y Prados (2007: 330 y 349). 
ACLARANDO TINTES DEMASIADO OSCUROS. LA ECONOMÍA ESPAÑOLA EN EL SIGLO XVIII

\begin{tabular}{|c|c|c|c|c|c|c|c|}
\hline AÑOS & INGLATERRA & HOLANDA & ESPAÑa & $\begin{array}{c}\text { NORTE Y CENTRO } \\
\text { DE ITALIA }\end{array}$ & FRANCIA & ALEMANIA & EUROPA \\
\hline $\mathbf{1 5 0 0}$ & 1,00 & 1,00 & 1,00 & 1,00 & 1,00 & 1,00 & 1,00 \\
\hline $\mathbf{1 6 0 0}$ & 0,95 & 1,16 & 0,99 & 0,87 & 0,98 & 0,94 & 0,93 \\
\hline $\mathbf{1 7 0 0}$ & 1,33 & 1,35 & 0,98 & 0,93 & 1,08 & 0,99 & 1,03 \\
\hline $\mathbf{1 7 5 0}$ & 1,51 & 1,41 & 0,90 & 1,01 & 1,12 & 1,02 & 1,07 \\
\hline $\mathbf{1 8 0 0}$ & 1,42 & 1,28 & 0,88 & 0,92 & 1,06 & 1,03 & 1,00 \\
\hline $\mathbf{1 8 7 0}$ & 2,46 & 1,73 & 0,94 & 1,03 & 1,41 & 1,51 & 1,46 \\
\hline
\end{tabular}

Cuadro 1. PIB per cápita en seis países europeos y en el conjunto de Europa, 1500-1800. (Índices con base 1 en 1500). Fuente: Malanima (2011): 189.

El Cuadro 1 recoge que, entre 1500 y 1800, según Malanima, el PIB por habitante europeo se estancó, el de la Europa meridional retrocedió, los de Alemania y Francia apenas crecieron y solo los de Holanda e Inglaterra registraron un aumento significativo. En cuanto al Setecientos, la imagen que se observa es aún más negativa: el PIB per cápita habría disminuido en el conjunto de Europa y en cuatro de los seis países contemplados; solo en Inglaterra y Alemania (y de manera bastante moderada) habría aumentado en el siglo XVIII. En general, el PIB por habitante habría tendido a elevarse en las fases de retroceso o de débil alza de la población y a caer en las de claro ascenso de esta. Es significativo que la etapa de mayor crecimiento demográfico de la Edad Moderna, la segunda mitad del Setecientos, aparezca como uno de los períodos en los que peor balance arrojó el PIB per cápita en el conjunto del Viejo Continente y en la mayor parte de sus territorios. Por tanto, queda claramente esbozado un mundo en el que las fuerzas malthusianas predominaban casi siempre sobre las smithianas ${ }^{16}$.

Dos fenómenos han propiciado la introducción de retoques metodológicos en la estimación del crecimiento agrario por la vía de la demanda. De un lado, la imagen marcadamente pesimista que se infiere del movimiento a largo plazo de los salarios, la variable más trascendental en ese tipo de experimentos, no se compadece bien con otras evidencias que apuntan a un cierto progreso económico o, cuando menos, a la inexistencia de un deterioro económico en el largo plazo en la mayoría de los territorios europeos entre 1500 y 1800. Así, por ejemplo, en Inglaterra, la renta de los factores de producción elaborada por Clark, en la que los salarios marcan claramente la pauta, diseña un deprimente cuadro malthusiano de estancamiento de los niveles de vida y de productividad desde la Baja Edad Media hasta finales de la Moderna ${ }^{17}$. Sin embargo, numerosas

16. Antes de la Revolución Industrial, los rendimientos decrecientes en la agricultura habrían prevalecido sobre los crecientes obtenidos en la industria y el comercio (MALANIMA, 2009: XVI).

17. CLARK (2010). 
evidencias sugieren que el progreso económico no fue insignificante en las campiñas, las aldeas y las ciudades inglesas en ese período: la mayor diversidad de las dietas, la práctica desaparición de las hambrunas, la disponibilidad de nuevos y más baratos bienes de consumo, el aumento de la riqueza de los testadores, el incremento de las tasas de alfabetización, el mayor número de ocupaciones y la transformación del built environment ${ }^{18}$.

Por otro lado, han tendido a aumentar las dudas acerca de que el jornal masculino, habitualmente de un albañil de una ciudad importante, multiplicado por un número fijo de días de trabajo por año, casi siempre 250 , constituya un buen indicador de la renta por habitante. Y ello, cuando menos, por dos razones: una, porque las rentas territoriales y las del capital evolucionaron a menudo de manera bastante distinta a las rentas laborales ${ }^{19}$; y dos, porque la intensidad en el uso del factor trabajo registró variaciones importantes en el transcurso de la Edad Moderna $^{20}$, lo que tuvo efectos relevantes en los ingresos anuales de las familias de asalariados ${ }^{21}$.

Estas y otras consideraciones han inducido a los especialistas a introducir varios retoques en la metodología empleada inicialmente para la estimación del producto agrario por la vía de la demanda: 1) algunos han asumido que el número anual de días trabajados por los asalariados no permaneció constante en el tiem$\left.\mathrm{po}^{22} ; 2\right)$ otros han considerado que el aumento del número de jornadas laboradas al año por los asalariados pudo compensar, total o parcialmente, el descenso de la capacidad adquisitiva de los jornales ${ }^{23}$; 3) Álvarez-Nogal y Prados han construido nuevas variables proxies del ingreso por habitante mediante el cómputo de salarios y rentas territoriales con sus ponderaciones correspondientes ${ }^{24}$; y 4) Pfister ha introducido cambios en la dieta empleada inicialmente para calcular de nuevo el consumo por habitante de productos agrarios alemán en las distintas fase ${ }^{25}$.

18. Broadberry, Campbell, Klein, Overton y van LeEuwen (2011: 2).

19. Hoffman, Jacks, Levin y Lindert (2002: 329); Álvarez-Nogal y Prados (2013: 4).

20. VOTH (1998); De VRIES (1994).

21. Utilizando la información suministrada por los contratos de trabajo anuales, Humphries y Weisdorf han demostrado que el número de días trabajados por año por los asalariados aumentó notablemente en Inglaterra entre la etapa posterior a la Peste Negra y la época de la Revolución Industrial, lo que permite conciliar mucho mejor la evolución del PIB per cápita y los ingresos anuales de los trabajadores ingleses (HuMPHRIES y WeISDORF, 2017: 4-5).

22. Malanima (2006: 100-101); Pfister supone que el factor trabajo se intensificó en Alemania un 25\% en la segunda mitad del siglo XVIII y un 5\% en la primera del XIX (PFISTER, 2011: 11-12).

23. Álvarez-Nogal y Prados (2013: 9).

24. Otorgan una ponderación del 75\% a las rentas salariales y del 25\% a las territoriales (ÁLVAREZ-Nogal y PRAdos, 2013: 9). Malanima, por su parte, considera inútil la incorporación de las rentas territoriales y de las rentas del capital, por su impacto insignificante en el consumo por habitante de productos agrarios (MALANIMA, 2011: 179).

25. Supone que se registró una sustitución parcial de carne por cereales en el siglo XVI y otra de granos por patatas y tropical groceries en el XVIII (PFISTER, 2011: 4 y 11). 
Estos retoques metodológicos han propiciado nuevas estimaciones; estas han supuesto la revisión al alza de los crecimientos agrario y económico en la Europa moderna. Así, por ejemplo, las cifras ofrecidas para España por Álvarez-Nogal y Prados en 2013 resultan menos desalentadoras que las que habían propuesto en 2007²6: los nuevos cálculos implican un crecimiento del PIB per cápita, aunque a la modestísima tasa del 0,026-0,027\%, entre 1500 y 1800, incremento que se intensificaría en el siglo XVIII, a una tasa del 0,11-0,12\% de 1700 a $1800^{27}$.

Todos estos cambios han introducido mejoras en las estimaciones del crecimiento agrario por la vía de la demanda, pero subsisten problemas de envergadura cuya resolución no parece factible en este marco metodológico. En primer lugar, las rentas salariales no constituían la principal fuente de ingresos de la mayoría de las familias rurales, claramente predominantes en la Europa medieval y moderna. El grueso de tales familias, en gran parte del continente, poseía una explotación agraria cuyos ingresos netos, en especie y en metálico, integraban la mayoría o una porción relevante de sus rentas. Por tanto, las variables proxies de la renta por habitante empleadas en las funciones de consumo, los jornales, los salarios anuales o un índice de rentas laborales y territoriales, no pueden reflejar de forma satisfactoria las variaciones en los ingresos de las familias rurales. En segundo lugar, en economías en las que el autoconsumo familiar absorbía un alto porcentaje de los frutos y esquilmos obtenidos por la mayor parte de las explotaciones campesinas, las funciones de consumo solo pueden aspirar a captar una fracción de las alteraciones en el producto agrario ${ }^{28}$. Y, en tercer lugar, la determinación precisa de las rentas salariales anuales de las familias, que constituiría en todo caso la variable proxy más apropiada de la renta por habitante, exigiría conocer los jornales de diversos tipos de trabajadores urbanos y, sobre todo, rurales; la evolución del número de días trabajados al año; las tasas de actividad femenina e infantil y sus respectivas trayectorias, y los salarios de las mujeres y de los menores de 16 años. En realidad, en la mayoría de los casos, la información disponible se circunscribe a salarios urbanos masculinos de un reducido elenco de profesiones.

Aparte de lo dicho hasta aquí, ¿pudo haber retrocedido el producto agrario por habitante en la segunda mitad del siglo XVIII, como muestran las distintas

26. Entonces arrojaban un descenso del PIB por habitante del 7,1\% entre 1530 y 1787 , y del 2,1\% entre 1700 y 1787 (Álvarez-Nogal y Prados, 2007: 353).

27. En este trabajo, los autores citados ofrecen dos estimaciones distintas de la evolución del PIB por habitante en siete países europeos: «In panel A, the benchmark stimates for 1850 are derived throught a short-cut approach and expressed in 1850 US relative prices. In panel $\mathrm{B}$, the benchmark is provided by Maddison's estimates expressed in Geary-Khamis 1990 dollars» (Álvarez-Nogal y PRADOs, 2013: 22-23). En el caso de España, el uso de paridades del poder adquisitivo de divisas de distinta fecha apenas afecta a las tasas de crecimiento del PIB por habitante entre 1500 y 1800 . En el texto se ofrecen los índices del PIB per cápita de Reino Unido, Holanda, Alemania, Francia, Italia, España y Suecia en distintas fechas entre 1300 y 1850.

28. En la España de finales del Antiguo Régimen, la mitad del producto agrario bruto campesino se destinaba al autoconsumo familiar y al reempleo en la propia explotación (GARCía SANZ, 1985: 66). 
estimaciones realizadas por la vía de la demanda, fase en la que la mortalidad disminuyó en diversos países de Europa occidental ${ }^{29}$, incluso en la España interior? ${ }^{30}$. Consideramos que no.

Es lógico, pues, que las crecientes dudas, inconsistencias y problemas detectados indujesen a destacados especialistas a relegar la vía de la demanda y a priorizar la vía del producto, siempre que se dispusiese de base documental suficiente, para estimar el crecimiento agrario de los distintos países del Viejo Continente en la época preindustrial ${ }^{31}$. Para el caso de España, Álvarez-Nogal, Prados y Santiago-Caballero han reconocido que las estimaciones realizadas mediante la vía de la demanda se han basado en evidencias empíricas limitadas sobre salarios y rentas territoriales y en supuestos arriesgados acerca de los valores de las elasticidades precio y renta de demanda. Y que el recurso a los diezmos para estimar el crecimiento agrario requiere el empleo de supuestos bastante menos severos. En definitiva, han acabado por otorgar preferencia a la vía del producto ${ }^{32}$.

Tanto para Inglaterra como para Holanda, las nuevas estimaciones del crecimiento agrario por la vía del producto han arrojado balances bastante más positivos que las anteriores por la vía de la demanda. En Inglaterra, las recientes cifras de Broadberry, Campbell, Klein, Overton y van Leeuwen entrañan un incremento del producto agrario por habitante del 6,3\% entre 1500 y $1800^{33}$. En cuanto a España, sin embargo, los cálculos efectuados por Álvarez-Nogal, Prados y Santiago-Caballero sobre un heterogéneo conjunto de series decimales publicadas siguen arrojando números rojos, aunque moderan algo la espeluznante visión del desempeño del sector agrario en la Edad Moderna previamente sustentada, en especial en el siglo XVIII. Así, entre 1500-1519 y 1780-1799, el producto agrario por habitante retrocedería un $23,8 \%$, frente a la caída del 36,1\% estimada por la vía de la demanda; y entre 1700-1719 y 1780-1799, el descenso sería del 2,2\%, en vez de alcanzar el 17,3\% En el epígrafe siguiente aportaremos evidencias y argumentos distintos, relativos al Setecientos, en favor de una hipótesis bien diferente: resulta poco verosímil que el producto agrario por habitante tendiese a estancarse o a contraerse en el conjunto de España en dicha centuria.

29. Valdin (1991); Schofield y Reher (1991); Chesnais (1986); Perrenoud (2001).

30. Llopis, Bernardos y Velasco (2015); Abarca, llopis, Sebastián, Bernardos y Velasco (2015); Abarca, Llopis, Sánchez Salazar y Velasco (2016); Abarca (2017).

31. Van Zanden y van Leeuwen han dicho: "What is missing, in our opinion, is a consistent set of estimates of national accounts via the output approach of European countries in the pre-1800 period, making it possible to study the process of economic growth in detail» (VAN ZANDEN y VAN LEEUwEN, 2012: 120).

32. Álvarez-Nogal, Prados y Santiago-Caballero (2016: 2).

33. Broadberry, Campbell, Klein, Overton y van Leeuwen (2015: 233-234 y 242).

34. Álvarez-Nogal, Prados y Santiago-Caballero (2016: 25). 


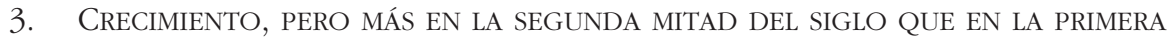

Vamos a aproximarnos al crecimiento de la población y de la economía españolas en el siglo XVIII, así como a sus respectivas distribuciones en el espacio y en el tiempo, a través de los índices regionales y nacional de bautismos; de la evolución de la ratio defunciones/bautizados en varios territorios del interior y de la periferia costera; del examen crítico de la documentación decimal manejada por Álvarez-Nogal, Prados y Santiago-Caballero, por el Grupo Complutense de Historia Económica Moderna ${ }^{35}$ y por otros colegas ${ }^{36}$; de la trayectoria de la tasa de urbanización; de diverso material cuantitativo y cualitativo sobre la expansión de las actividades no agrarias en el mundo rural en la segunda mitad del Setecientos, y de parte de las evidencias disponibles acerca del desempeño del comercio interior y exterior en dicha centuria.

\subsection{La evolución de la población: bautizados, difuntos y crisis demográficas}

En el Cuadro 2 (a, b, c y d) y en el Gráfico 1 presentamos los índices decenales ${ }^{37}$ regionales, macrorregionales y nacional de bautizados del período 1700$1809^{38}$. Antes de pasar a su comentario, conviene abordar un par de cuestiones relativas al uso de tales índices para la medición del crecimiento demográfico. Primera, el número de nacidos era, sin duda, mayor que el de bautizados y la dimensión relativa de la diferencia entre uno y otro varió durante el siglo XVIII, fundamentalmente según se alteró el período medio transcurrido entre el nacimiento y el bautizo solemne. Dicho intervalo promedio descendió en las dos Castillas desde los 10-11 días hacia 1705 hasta los 3-4 a finales del Setecientos ${ }^{39}$.

35. Hernández y Pérez Romero (2008); Sebastián, García Montero, Bernardos y Zafra (2008); Pérez Romero (2009); Llopis y GonZÁlez Mariscal (2010); AbarCa (2015: 272-331); Cuervo (2015: 351434); Llopis, Sebastián, Bernardos, Velasco y Abarca (2018).

36. Anes (1970); García Sanz (1977); Goy y Le Roy Ladurie (1982); Bilbao y Fernández de Pinedo (1984); Ardit (1989); Marcos (1989); Melón (1989: 75-106); Pérez Picazo (1989); DuráN y Feliu (2008); Fernández de Pinedo y García ZúÑIga (2008); Jover y Manera (2009); LANZa (2008) y (2010); Latorre (2010); Álvarez-Nogal, Prados y Santiago-Caballero (2016); Catalán (2008 y 2018 ).

37. No podemos ofrecer índices anuales de España y de algunas regiones porque solo disponemos de información decenal sobre los bautizados en Galicia, Asturias, País Vasco y Baleares.

38. Las muestras que sustentan los índices regionales son las siguientes: Andalucía 76 parroquias, Aragón 45, Canarias 62, Cantabria 34 localidades, Castilla y León 492, Castilla-La Mancha 125, Comunidad de Madrid 30, Navarra 53, Cataluña 254 parroquias, Comunidad Valenciana 182, Extremadura 37, Galicia más de 200 parroquias, Baleares 6 municipios mallorquines y 13 parroquias menorquinas, La Rioja 39 localidades, País Vasco 151 parroquias, Asturias 43 y Murcia 16 localidades. En total, cerca de 1.800 núcleos de población.

39. El Grupo Complutense de Historia Económica Moderna ha calculado dicho lapso promedio en muestras representativas de las provincias de Burgos, Palencia, Zamora, Ávila, Madrid, Ciudad Real y Albacete hacia 1705, 1730, 1755, 1775, 1790 y 1800. 
Considerando la mortalidad en los primeros 10-11 días de vida, puede estimarse en qué porcentajes los bautizados infravaloraban a los nacidos a comienzos y a finales de la centuria ${ }^{40}$. Y, segunda, los índices de bautizados permiten una aceptable aproximación al crecimiento de la población siempre que la tasa media anual de natalidad registre variaciones pequeñas o permanezca casi constante en el período objeto de estudio ${ }^{41}$. En este mismo artículo aportaremos nuevas evidencias sobre la estabilidad de dicha tasa en las dos Castillas en la segunda mitad del siglo XVIII.

\begin{tabular}{|c|c|c|c|c|c|c|c|c|}
\hline DÉCADAS & ARAGÓN & $\begin{array}{c}\text { CASTILLA } \\
\text { Y LEÓN }\end{array}$ & $\begin{array}{c}\text { CASTILLA-LA } \\
\text { MANCHA }\end{array}$ & $\begin{array}{c}\text { COMUNIDAD } \\
\text { DE MADRID }\end{array}$ & EXTREMADURA & $\begin{array}{c}\text { LA } \\
\text { RIOJA }\end{array}$ & $\begin{array}{c}\text { ESPAÑA } \\
\text { INTERIOR }\end{array}$ & ANDALUCía \\
\hline $\mathbf{1 7 0 0 - 1 7 0 9}$ & 100,0 & 100,0 & 100,0 & 100,0 & 100,0 & 100,0 & $\mathbf{1 0 0 , 0}$ & $\mathbf{1 0 0 , 0}$ \\
\hline $\mathbf{1 7 1 0 - 1 7 1 9}$ & 100,9 & 97,5 & 95,3 & 93,5 & 97,9 & 90,7 & $\mathbf{9 7 , 1}$ & $\mathbf{9 8 , 6}$ \\
\hline $\mathbf{1 7 2 0 - 1 7 2 9}$ & 113,9 & 112,3 & 111,0 & 110,5 & 112,9 & 101,4 & $\mathbf{1 1 1 , 8}$ & $\mathbf{1 0 9 , 3}$ \\
\hline $\mathbf{1 7 3 0 - 1 7 3 9}$ & 113,5 & 108,3 & 109,7 & 104,7 & 108,9 & 98,4 & $\mathbf{1 0 9 , 0}$ & $\mathbf{1 0 6 , 1}$ \\
\hline $\mathbf{1 7 4 0 - 1 7 4 9}$ & 118,1 & 112,3 & 114,1 & 110,7 & 117,3 & 99,1 & $\mathbf{1 1 3 , 7}$ & $\mathbf{1 1 1 , 8}$ \\
\hline $\mathbf{1 7 5 0 - 1 7 5 9}$ & 128,6 & 122,6 & 122,5 & 120,3 & 128,1 & 105,1 & $\mathbf{1 2 3 , 4}$ & $\mathbf{1 1 6 , 2}$ \\
\hline $\mathbf{1 7 6 0 - 1 7 6 9}$ & 148,0 & 127,9 & 129,9 & 122,0 & 128,8 & 105,0 & $\mathbf{1 3 0 , 5}$ & $\mathbf{1 1 6 , 1}$ \\
\hline $\mathbf{1 7 7 0 - 1 7 7 9}$ & 144,7 & 126,6 & 132,7 & 117,2 & 134,1 & 101,0 & $\mathbf{1 3 0 , 3}$ & $\mathbf{1 1 4 , 9}$ \\
\hline $\mathbf{1 7 8 0 - 1 7 8 9}$ & 142,5 & 134,8 & 135,8 & 120,0 & 139,6 & 106,5 & $\mathbf{1 3 4 , 8}$ & $\mathbf{1 1 1 , 8}$ \\
\hline $\mathbf{1 7 9 0 - 1 7 9 9}$ & 157,7 & 142,5 & 148,6 & 135,9 & 148,9 & 115,0 & $\mathbf{1 4 5 , 7}$ & $\mathbf{1 2 6 , 4}$ \\
\hline $\mathbf{1 8 0 0 - 1 8 0 9}$ & 155,1 & 125,0 & 128,7 & 120,2 & 145,2 & 111,4 & $\mathbf{1 3 2 , 1}$ & $\mathbf{1 1 8 , 2}$ \\
\hline
\end{tabular}

Cuadro 2a. Índices de bautismos en la España interior y Andalucía, 1700-1809 (Base 100, 1700-1709). Fuentes: Llopis (2004c); Llopis y Sebastián (2007); para Cataluña, FerRER (2007), pp. 58-60; para las dos Castillas, Madrid y Andalucía, los índices se han elaborado con muestras ampliadas por el Grupo Complutense de Historia Económica Moderna a partir de Abarca (2015), Cuervo (2015), GonZález Agudo (2015), GonzÁLEZ Mariscal (2013) y Llopis, Sebastián, Sánchez Salazar, Abarca y Velasco (2017); para Murcia, Grupo Complutense de Historia Económica Moderna y llopis, Alonso, Fontanilla, Hípola, Méndez y Ramos (2017).

40. Alberto Sanz nos ha proporcionado amablemente las tasas de supervivencia de los niños a las 24 horas, a la semana y a las dos semanas de nacer en varias localidades de Madrid en 1865-1889. Suponiendo que la mortalidad en los primeros días de vida era, en la segunda mitad del siglo XVIII, similar o un poco más alta que en tales fechas, resulta verosímil que los nacidos superasen en un 5,5-6\% a los bautizados en ambas Castillas a comienzos del Setecientos. Este porcentaje tendería a reducirse conforme disminuyó el lapso entre parto y bautismo. Por consiguiente, el índice de bautizados sobrevalora, al menos en amplias zonas del interior peninsular, el crecimiento de los nacidos en el siglo XVIII.

41. Llopis y PÉREZ MOREda (2003: 126-127). 
ACLARANDO TINTES DEMASIADO OSCUROS. LA ECONOMÍA ESPAÑOLA EN EL SIGLO XVIII

\begin{tabular}{|c|c|c|c|c|c|c|c|}
\hline DÉCADAS & CATALUÑA & $\begin{array}{c}\text { COMUNIDAD } \\
\text { VALENCIANA }\end{array}$ & $\begin{array}{c}\text { REGIÓN DE } \\
\text { MURCIA }\end{array}$ & $\begin{array}{c}\text { ESPAÑA } \\
\text { MEDITERRÁNEA }\end{array}$ & BALEARES & CANARIAS & $\begin{array}{c}\text { ESPAÑA } \\
\text { INSULAR }\end{array}$ \\
\hline $\mathbf{1 7 0 0 - 1 7 0 9}$ & 100,0 & 100,0 & 100,0 & $\mathbf{1 0 0 , 0}$ & 100,0 & 100,0 & $\mathbf{1 0 0 , 0}$ \\
\hline $\mathbf{1 7 1 0 - 1 7 1 9}$ & 101,1 & 102,9 & 113,0 & $\mathbf{1 0 3 , 4}$ & 106,8 & 106,6 & $\mathbf{1 0 6 , 7}$ \\
\hline $\mathbf{1 7 2 0 - 1 7 2 9}$ & 115,1 & 133,8 & 134,4 & $\mathbf{1 2 5 , 4}$ & 96,5 & 108,2 & $\mathbf{1 0 2 , 2}$ \\
\hline $\mathbf{1 7 3 0 - 1 7 3 9}$ & 124,5 & 153,8 & 146,3 & $\mathbf{1 3 9 , 5}$ & 104,3 & 121,3 & $\mathbf{1 1 2 , 6}$ \\
\hline $\mathbf{1 7 4 0 - 1 7 4 9}$ & 125,9 & 158,2 & 169,9 & $\mathbf{1 4 5 , 1}$ & 110,7 & 119,2 & $\mathbf{1 1 4 , 8}$ \\
\hline $\mathbf{1 7 5 0 - 1 7 5 9}$ & 142,2 & 188,2 & 197,8 & $\mathbf{1 6 8 , 6}$ & 106,5 & 124,6 & $\mathbf{1 1 5 , 3}$ \\
\hline $\mathbf{1 7 6 0 - 1 7 6 9}$ & 149,2 & 213,8 & 206,3 & $\mathbf{1 8 3 , 5}$ & 117,6 & 131,1 & $\mathbf{1 2 4 , 2}$ \\
\hline $\mathbf{1 7 7 0 - 1 7 7 9}$ & 158,7 & 225,8 & 210,4 & $\mathbf{1 9 3 , 3}$ & 119,1 & 136,9 & $\mathbf{1 2 7 , 8}$ \\
\hline $\mathbf{1 7 8 0 - 1 7 8 9}$ & 169,6 & 225,3 & 231,1 & $\mathbf{2 0 0 , 8}$ & 114,9 & 139,9 & $\mathbf{1 2 7 , 0}$ \\
\hline $\mathbf{1 7 9 0 - 1 7 9 9}$ & 193,0 & 251,5 & 234,4 & $\mathbf{2 2 2 , 7}$ & 116,5 & 148,5 & $\mathbf{1 3 2 , 0}$ \\
\hline $\mathbf{1 8 0 0 - 1 8 0 9}$ & 192,8 & 255,7 & 222,4 & $\mathbf{2 2 2 , 8}$ & 122,5 & 165,2 & $\mathbf{1 4 3 , 3}$ \\
\hline
\end{tabular}

Cuadro 2b. Índices de bautismos en las Españas mediterránea e insular, 1700-1809 (Base 100, 1700-1709). Fuentes: Las citadas en el Cuadro 2a.

\begin{tabular}{|c|c|c|c|c|c|}
\hline DÉCADAS & GALICIA & ASTURIAS & PAÍS VASCO & NAVARRA & ESPAÑA SEPTENTRIONAL \\
\hline $\mathbf{1 7 0 0 - 1 7 0 9}$ & 100,0 & 100,0 & 100,0 & 100,0 & $\mathbf{1 0 0 , 0}$ \\
\hline $\mathbf{1 7 1 0 - 1 7 1 9}$ & 96,5 & 98,4 & 95,5 & 98,0 & $\mathbf{9 6 , 7}$ \\
\hline $\mathbf{1 7 2 0 - 1 7 2 9}$ & 107,0 & 102,9 & 102,9 & 101,2 & $\mathbf{1 0 5 , 1}$ \\
\hline $\mathbf{1 7 3 0 - 1 7 3 9}$ & 107,0 & 108,3 & 109,9 & 102,8 & $\mathbf{1 0 6 , 8}$ \\
\hline $\mathbf{1 7 4 0 - 1 7 4 9}$ & 108,1 & 112,7 & 114,0 & 106,2 & $\mathbf{1 0 8 , 7}$ \\
\hline $\mathbf{1 7 5 0 - 1 7 5 9}$ & 116,3 & 125,9 & 116,3 & 103,6 & $\mathbf{1 1 6 , 1}$ \\
\hline $\mathbf{1 7 6 0 - 1 7 6 9}$ & 119,8 & 135,8 & 119,0 & 111,5 & $\mathbf{1 2 1 , 0}$ \\
\hline $\mathbf{1 7 7 0 - 1 7 7 9}$ & 117,4 & 141,1 & 122,1 & 120,5 & $\mathbf{1 2 1 , 4}$ \\
\hline $\mathbf{1 7 8 0 - 1 7 8 9}$ & 131,4 & 146,6 & 124,3 & 121,9 & $\mathbf{1 3 1 , 0}$ \\
\hline $\mathbf{1 7 9 0 - 1 7 9 9}$ & 133,7 & 148,1 & 129,0 & 129,8 & $\mathbf{1 3 4 , 2}$ \\
\hline $\mathbf{1 8 0 0 - 1 8 0 9}$ & 133,7 & 144,1 & - & 136,0 & $\mathbf{1 3 3 , 9}$ \\
\hline
\end{tabular}

Cuadro 2c. Índices de bautismos en la España septentrional, 1700-1809

(Base 100, 1700-1709). Fuentes: Las citadas en el Cuadro 2a. 


\begin{tabular}{|c|c|c|c|c|c|c|}
\hline DÉCADAS & $\begin{array}{c}\text { ESPAÑA } \\
\text { INTERIOR }\end{array}$ & $\begin{array}{c}\text { ESPAÑA } \\
\text { MEDITERRÁNEA }\end{array}$ & ANDALUCía & $\begin{array}{c}\text { ESPAÑA } \\
\text { SEPTENTRIONAL }\end{array}$ & $\begin{array}{c}\text { ESPAÑA } \\
\text { INSULAR }\end{array}$ & ESPAÑA \\
\hline $1700-1709$ & 100,0 & 100,0 & 100,0 & 100,0 & 100,0 & 100,0 \\
\hline $1710-1719$ & 97,1 & 103,4 & 98,6 & 96,7 & 106,7 & 98,7 \\
\hline $1720-1729$ & 111,8 & 125,4 & 109,3 & 105,1 & 102,2 & 112,1 \\
\hline $1730-1739$ & 109,0 & 139,5 & 106,1 & 106,8 & 112,6 & 113,8 \\
\hline $1740-1749$ & 113,7 & 145,1 & 111,8 & 108,7 & 114,8 & 118,1 \\
\hline $1750-1759$ & 123,4 & 168,6 & 116,2 & 116,1 & 115,3 & 128,6 \\
\hline $1760-1769$ & 130,5 & 183,5 & 116,1 & 121,0 & 124,2 & 135,5 \\
\hline $1770-1779$ & 130,3 & 193,3 & 114,9 & 121,4 & 127,8 & 137,2 \\
\hline $1780-1789$ & 134,8 & 200,8 & 111,8 & 131,0 & 127,0 & 142,0 \\
\hline $1790-1799$ & 145,7 & 222,7 & 126,4 & 134,2 & 132,0 & 153,6 \\
\hline $1800-1809$ & 132,1 & 222,8 & 118,2 & 133,9 & 143,3 & 147,9 \\
\hline
\end{tabular}

Cuadro 2d. Índices macrorregionales y nacional de bautismos, 1700-1809

(Base 100, 1700-1709). Fuentes: Las citadas en el Cuadro 2a.

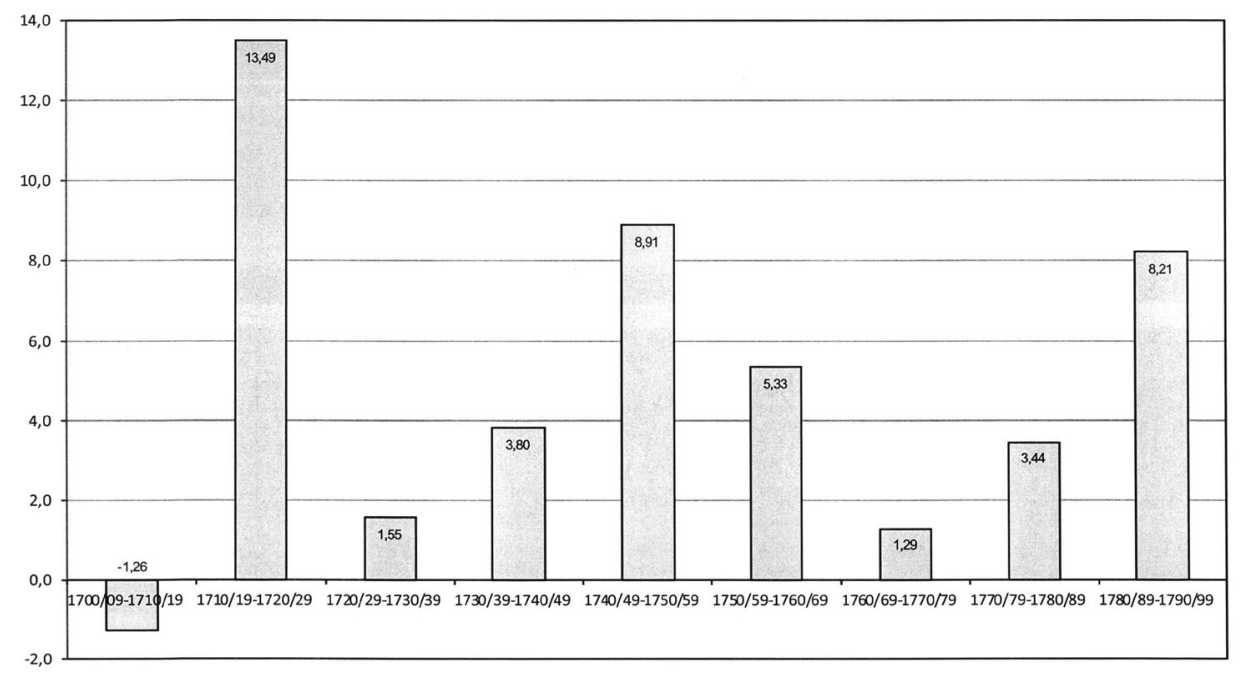

Gráfico 1. Incrementos por décadas del índice de bautismos de España, 1700-1799 (en porcentajes). Fuentes: Las citadas en el Cuadro 2a.

El índice de bautizados de España se incrementó un 53,6\% entre la primera y la última década del siglo XVIII. Como el intervalo medio entre el nacimiento y el bautismo solemne se acortó significativamente en esa centuria, el aumento de 
los nacidos debió de ser un poco menor, quizá próximo a un 50\%. Los bautismos crecieron de manera más intensa y continua después de 1750 que antes de esta fecha: su ascenso se operó a una tasa media anual acumulativa del 0,42\% entre $1700-1709$ y $1740-1749$, y a una del 0,53\% entre $1750-1759$ y $1790-1799$. Como la natalidad fue anormalmente baja en la segunda mitad de la década de 1700, tales tasas exageran un tanto la velocidad del crecimiento de la población española entre la primera y la quinta décadas del siglo, así como entre la primera y la última, pero, importa destacarlo, no entre $1750-1759$ y $1790-1799^{42}$. Ello implica que la diferencia real entre la fortaleza del incremento demográfico en la primera y en la segunda mitad del siglo fue más amplia de lo que indican las tasas calculadas: es probable que el ritmo promedio de alza de la población fuese cerca de un 50\% mayor entre 1750 y 1799 que entre 1700 y 1749. Si los resultados fueron mejores cuando la densidad demográfica era más alta, el modelo malthusiano no puede ser la herramienta esencial para interpretar lo acontecido en la economía española durante el siglo XVIII ${ }^{43}$.

El Gráfico 1 confirma que el crecimiento demográfico del Setecientos en España fue más discontinuo en la primera mitad que en la segunda. En aquella hubo tres decenios de aumento exiguo (1700-170944 y 1730-1739) o negativo (1710-1719), mientras que en esta solo hubo uno (1770-1779) sin que se registrase, además, un retroceso respecto a la década precedente. En cualquier caso, el índice de bautismos sugiere que el crecimiento demográfico en la España del siglo XVIII tuvo, en general, un alto grado de discontinuidad y fue fruto, en gran medida, de tres oleadas expansivas relativamente cortas: la del decenio de 1720; la del de 1750, que se prolongó debilitada en la siguiente década, y la del de 1790. La más intensa fue la primera, pero conviene tener en cuenta que esta acaeció tras una fase de estancamiento y recesión demográfica que se extendió desde los primeros años del siglo XVIII hasta después del fin de la Guerra de Sucesión.

42. Hubiese sido deseable que las series arrancasen de 1695 para evitar la singularidad de la década de 1700 , base de los cálculos, pero ello nos habría obligado a trabajar con muestras de bautismos mucho más reducidas y bastante menos representativas en la mayoría de las provincias.

43. En este punto coincidimos con las posiciones más recientes de Álvarez-Nogal y PRADOS (2013: 24): el PIB per cápita aumentó en España en las fases de mayor crecimiento de la población.

44. Entre 1690-1699 y 1700-1709, el índice de bautizados se estancó o retrocedió en la España interior, Andalucía occidental y la España mediterránea, y solo aumentó en la España septentrional, por entonces en plena revolución del maíz (LLOPIS y SEBASTIÁN, 2007: 82-83). 


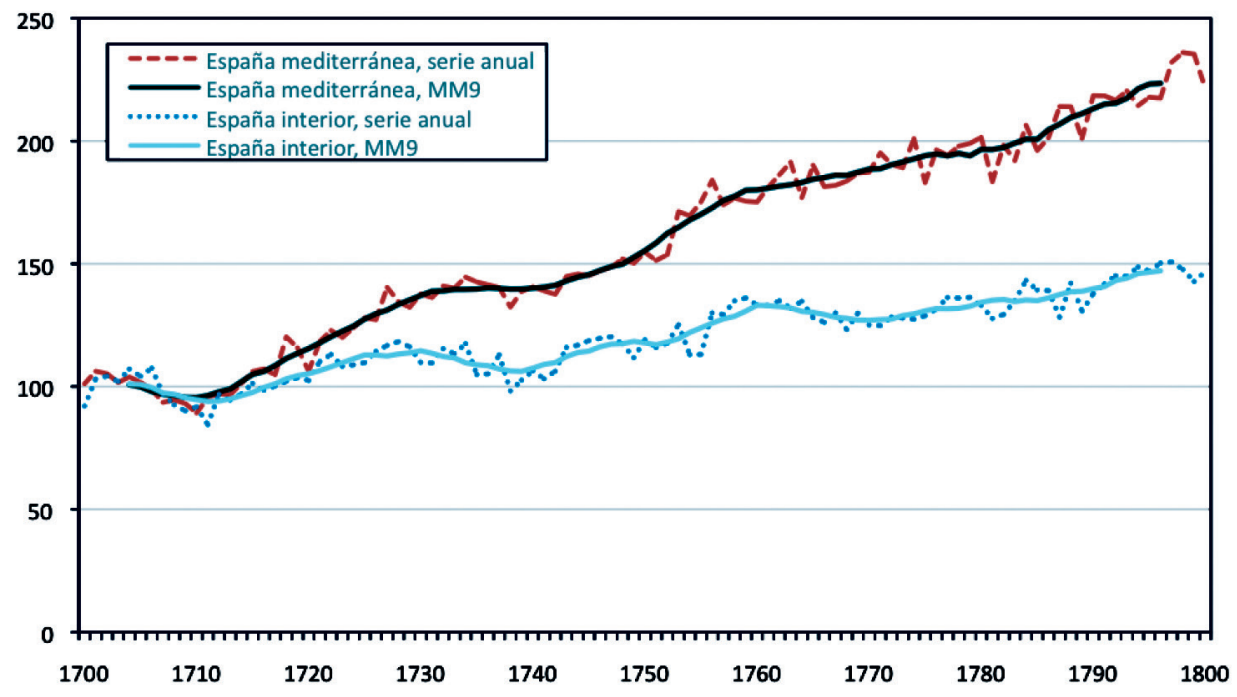

Gráfico 2. Índices de bautizados en las Españas mediterránea e interior, 1700-1800 (datos anuales y medias móviles de 9 años). Fuentes: Las citadas en el Cuadro 2a.

Carecemos de espacio para comentar la trayectoria de cada uno de los índices regionales, por lo que nos centraremos en destacar los rasgos más sobresalientes de la evolución de los macrorregionales.

Entre 1700-1709 y 1790-1799, el índice de bautizados creció un 122,7\% en la España mediterránea, un $45,7 \%$ en la España interior, un 34,2\% en la España septentrional, un 32,0\% en la España insular y un 26,4\% en Andalucía. En términos de velocidad del crecimiento demográfico, el conjunto del territorio puede dividirse en dos zonas: una, la España mediterránea; otra, el resto de regiones peninsulares e insulares. La dualidad es nítida en este caso: entre la primera y la última década del siglo XVIII, los bautizados crecieron al 0,89\% en la España mediterránea, al 0,42\% en la España interior, al 0,33\% en la España septentrional, al 0,31\% en la España insular y al 0,26\% en Andalucía. En el Gráfico 2, mediante el ejemplo de las Españas mediterránea e interior, se visualiza muy bien la magnitud de dicha dualidad.

En el presente trabajo no vamos a examinar en detalle la recesión demográfica y económica que tuvo lugar en los quince primeros años del siglo XIX ${ }^{45}$. No obstante, queremos indicar que las cifras del Cuadro 2 (a, b, c y d) corroboran dos extremos. Uno, su inhabitual dimensión en el conjunto de España: habría que retroceder muy atrás de 1700 para hallar descensos de intensidad similar entre decenios consecutivos. Dos, su diferente envergadura en los distintos espacios

45. Sobre uno de sus episodios más relevantes, véase Llopis y SÁNCHEz SALAZAR (2016). 
peninsulares e insulares: de 1790-1799 a 1800-1809, el índice de bautizados se contrajo un 9,3\% en la España interior, un 6,5\% en Andalucía y un 0,2\% en la España septentrional, a la par que aumentó un 0,04\% en la España mediterránea y un $8,6 \%$ en la España insular. En consecuencia, el fenómeno, inexistente en los archipiélagos y definido por un ligero traspiés en buena parte de las áreas litorales peninsulares, revistió una singular gravedad en el interior y en Andalucía ${ }^{46}$.

El crecimiento demográfico se distribuyó en el tiempo de manera bastante dispar en las diversas macrorregiones durante el siglo XVIII. Entre la primera y la quinta décadas del Setecientos y entre la quinta y la postrera, las tasas de crecimiento de los bautizados fueron del 0,32 y del 0,50\% en la España interior, del 0,93 y del 0,86\% en la España mediterránea, del 0,28 y del 0,25\% en Andalucía, del 0,21 y del 0,42\% en la España septentrional y del 0,35 y del 0,28\% en la España insular ${ }^{47}$. Por consiguiente, notable intensificación del crecimiento en el interior peninsular y en el norte; leve desaceleración, pero manteniendo una elevada velocidad expansiva en el Levante, y debilitamiento del ritmo de aumento en el sur y en los archipiélagos, territorios que ya partían de unas tasas de crecimiento relativamente mediocres en la primera mitad del Setecientos.

Para los espacios peninsulares es posible poner en perspectiva tales trayectorias y conviene hacerlo. Como hemos mostrado en otros trabajos ${ }^{48}$, las dimensiones del retroceso poblacional y económico de las distintas macrorregiones registrado a finales del siglo XVI y en buena parte del XVII, los momentos de arranque de la recuperación posterior y el ímpetu de la misma fueron también muy dispares. Primero, el que los índices de bautismos de la España mediterránea ya alcanzasen un fuerte ritmo de aumento en la segunda mitad del Seiscientos, lo que permitió a esta macrorregión recuperar y remontar en el decenio de 1680 los niveles perdidos a comienzos de la centuria, aminora la relevancia de la desaceleración detectada en el tránsito de la primera a la segunda mitad del siglo XVIII: cuando sus tasas de crecimiento pasaron de 0,93 a 0,86\%, el Levante llevaba casi cien años creciendo a uno de los ritmos promedio más elevados de Europa occidental. Segundo, la temprana recuperación del bache demográfico de finales del Quinientos y comienzos del Seiscientos en la España septentrional, ya en la segunda mitad del siglo XVII, realza el mérito de la aceleración observada en su índice de bautismos luego de 1750. Tercero, en el sur, al menos en Andalucía occidental, el reducido descenso del índice de bautizados entre 1590 y 1650 facilitó, desde el decenio de

46. Si las cifras del Cuadro 2a, por ejemplo, se comparan con las incluidas en LlOPIS y SEBASTIÁN (2007: 82-83), con la salvedad de que la muestra entonces utilizada era más pequeña, se aprecia que, en la España interior, habría que remontarse al tránsito entre las décadas de 1620 y 1630 para encontrar un retroceso del índice de bautismos comparable con el registrado entre 1790-1799 y 1800-1809.

47. Somos conscientes de que la evolución económica y demográfica de Baleares fue muy distinta de la de Canarias en el siglo XVIII. Sobre tales regiones véanse, por ejemplo, MaNERA (2001); BERNAL y MACÍAS (2007: 13-32); MOREY (2007: 303-315).

48. Llopis y Sebastián (2007); Llopis (2010); Sebastián (2013). 
1660, que estos se situasen por encima de los niveles de finales del siglo XVI, lo que matiza el mediocre ritmo de aumento observado para el conjunto de Andalucía en la primera mitad del Setecientos y su ligera desaceleración en su segunda mitad, si bien, como es obvio, no explica ese escaso dinamismo demográfico. Y cuarto, en la España interior, la macrorregión más severamente castigada por la recesión demográfica y económica del Seiscientos, la aceleración del ritmo de aumento del índice de bautizados en el tránsito de la primera a la segunda mitad del siglo XVIII se operó a la par de un logro que se había hecho esperar muchísimo tiempo, la recuperación de los niveles perdidos a finales del siglo XVI. En suma, las cifras del Cuadro 2 ( $\mathrm{a}, \mathrm{b}, \mathrm{c}$ y d) y las consideraciones efectuadas propician una lectura con dos caras complementarias. Apuntan, de un lado, a que los resultados demográficos y económicos fueron relativamente satisfactorios en el conjunto de España entre mediados y finales del Setecientos, sobre todo porque en la España interior el crecimiento de los bautismos se avivó notablemente y porque en la España mediterránea logró mantenerse en niveles muy altos tras bastantes décadas de veloz expansión de la población. Indican, de otro, e importa destacarlo, que, en todos los espacios de la España peninsular, por fin, el crecimiento del índice de bautismos se estaba operando en términos netos desde mediados del Setecientos, por encima definitivamente de los niveles máximos de finales del siglo XVI y comienzos del XVII. Da la impresión, pues, que las fuerzas malthusianas no estaban imponiéndose en la mayoría de sus territorios entre 1750 y 1800.

El Cuadro 3, que recoge la frecuencia, la intensidad media y un indicador sintético de las crisis de natalidad ${ }^{49}$, en lapsos de 25 años, en las Españas interior y mediterránea, también invita a un cierto optimismo acerca del desempeño demográfico y económico de la primera de dichas macrorregiones en la segunda mitad del Setecientos.

Efectivamente, en la España interior, entre 1700-1749 y 1750-1799, el número de crisis de natalidad se redujo a casi la mitad y el indicador sintético de las mismas $^{50}$, un 39\%; su intensidad media fue, por contra, un 9,7\% mayor en la segunda mitad del siglo XVIII que en la primera. En la España mediterránea, el índice sintético aumentó ligeramente, un 5,9\%, entre 1700-1749 y 1750-1799. Este pequeño repunte

49. Para la determinación y medición de las crisis de natalidad hemos seguido la misma metodología que Del PANTA y Livi-BACCi (1977) utilizaron para estudiar las de mortalidad, la de las medias móviles truncadas de 11 años eliminando el año de crisis, los dos máximos y los dos mínimos. Ahora bien, la volatilidad de los bautizados es mucho menor que la de las defunciones y, además, estamos empleando muestras muy grandes: 768 parroquias para la España interior y 452 para la España mediterránea. De ahí que hayamos decidido trabajar con un umbral de determinación de crisis de natalidad muy inferior al utilizado habitualmente en trabajos locales o provinciales sobre crisis de mortalidad. Hemos considerado que existía una crisis de natalidad siempre que el número de bautizados fuese inferior un 5\% o más a la correspondiente media truncada de 11 años.

50. Obsérvese que el indicador sintético integra dos de los factores fundamentales de las crisis, frecuencia e intensidad. 
obedeció a que, en el Levante, pesó un poco más el aumento de la frecuencia que la moderación de la intensidad de las crisis en la segunda mitad del Setecientos.

\begin{tabular}{|c|c|c|c|c|c|c|}
\hline & \multicolumn{3}{|c|}{ ESPAÑA INTERIOR } & \multicolumn{3}{c|}{ ESPAÑA MEDITERRÁNEA } \\
\hline PERÍODOS & NÚMERO & $\begin{array}{c}\text { INTENSIDAD } \\
\text { MEDIA (\%) }\end{array}$ & $\begin{array}{c}\text { INDICADOR } \\
\text { SINTÉTICO (\%) }\end{array}$ & NÚMERO & $\begin{array}{c}\text { INTENSIDAD } \\
\text { MEDIA (\%) }\end{array}$ & $\begin{array}{c}\text { INDICADOR } \\
\text { SINTÉTICO (\%) }\end{array}$ \\
\hline $\mathbf{1 7 0 0 - 1 7 2 4}$ & 4 & 8,2 & 32,8 & 2 & 8,9 & 17,8 \\
\hline $\mathbf{1 7 2 5 - 1 7 4 9}$ & 5 & 6,5 & 32,3 & 1 & 5,9 & 5,9 \\
\hline $\mathbf{1 7 5 0 - 1 7 7 4}$ & 2 & 9,0 & 18,1 & 1 & 5,2 & 5,2 \\
\hline $\mathbf{1 7 7 5 - 1 7 9 9}$ & 3 & 7,2 & 21,6 & 3 & 6,6 & 19,9 \\
\hline $\mathbf{1 7 0 0 - 1 7 4 9}$ & 9 & 7,2 & 65,1 & 3 & 7,9 & 23,7 \\
\hline $\mathbf{1 7 5 0 - 1 7 9 9}$ & 5 & 7,9 & 39,7 & 4 & 6,3 & 25,1 \\
\hline $\mathbf{1 7 0 0 - 1 7 9 9}$ & 14 & 7,5 & 104,8 & 7 & 7,0 & 48,8 \\
\hline
\end{tabular}

Cuadro 3. Frecuencia, intensidad media e indicador sintético de las crisis de natalidad en las Españas interior y mediterránea, 1700-1799. Fuentes: Las citadas en el Cuadro 2a.

Ahora bien, como muestra claramente el Cuadro 3, las crisis de natalidad tuvieron una magnitud bastante mayor en la España interior que en la España mediterránea en el conjunto del siglo XVIII. La principal diferencia entre ambos territorios no radicó en la intensidad de las crisis, sino en su frecuencia: una cada 7,1 años en el primero y una cada 14,3 en el segundo. El resultado de la comparación es el esperado: los baches de natalidad fueron menos habituales en regiones marítimas de producción agraria diversificada y fácil acceso al trigo de la mar que en territorios interiores donde los cereales suponían un elevado porcentaje de las cosechas y esquilmos.

Un estudio más desagregado muestra que el indicador sintético de crisis de natalidad, de la primera a la segunda mitad del siglo XVIII, descendió en ocho regiones (Cataluña, Valencia, Aragón, La Rioja, Castilla-La Mancha, Castilla y León y Cantabria) y aumentó en cuatro (Murcia, Extremadura, Andalucía y Navarra) ${ }^{51}$. En 1787, las primeras albergaban al $51,1 \%$ de la población española y las segundas al 26,4\%. Esta nueva información invita a un par de comentarios: uno, en la mayor parte de España, los reveses demográficos y económicos se moderaron desde mediados del Setecientos; y dos, el aumento de la entidad de las crisis de natalidad en la segunda mitad del siglo XVIII se concentró en las regiones meridionales de alto grado de desigualdad en la distribución de la renta y la riqueza, y de incremento del porcentaje de familias cuyos ingresos dependían, básicamente, de rentas salariales. El análisis de las crisis de natalidad permite vislumbrar dos Españas diferentes: la

51. Al carecer de series anuales de bautizados, no hemos podido efectuar el estudio de las crisis de natalidad para Galicia, Asturias, País Vasco, Baleares y Canarias. 
del predominio de los pequeños productores agrarios, donde se mitigó en alguna medida la inestabilidad demográfica y económica en la segunda mitad del Setecientos, y la de mayor presencia de familias de jornaleros y asalariados, donde aconteció lo contrario en dicho intervalo. La primera era hegemónica, pero la segunda era suficientemente grande como para frenar las mejoras económicas en el conjunto del país.

La salud es un componente esencial del bienestar de las sociedades, pero no disponemos de información suficiente para determinar la evolución de la esperanza de vida o de las tasas de supervivencia a distintas edades de los españoles en el siglo XVIII. No obstante, sí hemos podido construir dos variables proxies del movimiento a medio y largo plazo de la tasa bruta de mortalidad en varias regiones en esa centuria o, al menos, en su segunda mitad: la ratio defunciones/bautizados en lapsos de 20, 25 o 50 años y una estimación directa de las tasas medias brutas provinciales y regionales de mortalidad, también en intervalos de 20, 25 o 50 años, a través de los crecimientos vegetativos, de los registros censales y de la introducción de ciertos supuestos sobre la distribución en el tiempo de los saldos migratorios en los lapsos intercensales ${ }^{52}$.

\begin{tabular}{|c|c|c|c|}
\hline PERÍODOS & $\begin{array}{c}\text { TOTAL DE DEFUNCIONES/ } \\
\text { BAUTIZADOS }\end{array}$ & $\begin{array}{c}\text { DEFUNCIONES DE PÁRVULOS/ } \\
\text { BAUTIZADOS }\end{array}$ & $\begin{array}{c}\text { DEFUNCIONES DE } \\
\text { ADULTOS/BAUTIZADOS }\end{array}$ \\
\hline 1700-1724 & 96,6 & 49,2 & 47,0 \\
\hline 1725-1749 & 100,4 & 52,0 & 47,1 \\
\hline 1750-1774 & 88,2 & 48,4 & 40,3 \\
\hline 1775-1799 & 86,5 & 47,9 & 38,6 \\
\hline 1700-1749 & 98,6 & 50,7 & 47,0 \\
\hline 1750-1799 & 87,4 & 48,1 & 39,4 \\
\hline
\end{tabular}

Cuadro 4. Ratios defunciones/bautizados en las dos Castillas ${ }^{53}$, 1700-1799 (en porcentajes). Fuentes: Libros de defunciones, Archivo Histórico Nacional; Archivos Diocesanos de Ávila, Burgos, Ciudad Real, Getafe, Madrid, Palencia, Sigüenza y Zamora; Archivos Parroquiales de Miraflores de la Sierra, Barajas, San Martín de Valdeiglesias, Estremera, Fuentidueña de Tajo, Brea de Tajo, Carabaña, Guardo, Porto de Sanabria, Arcos, Cuevas del Valle, Maello y Cardeñosa; y https://familysearch.org.

52. Estas metodologías se describen y examinan de manera crítica en ABARCA, Llopis, SÁNCHEZ Salazar y Velasco (2016) y en llopis, Sebastián, Sánchez Salazar, Abarca y Velasco (2017). La inexistencia de un censo de población completo y fiable para finales del Seiscientos o comienzos del Setecientos nos ha impedido aplicar la segunda metodología a la primera mitad del siglo XVIII.

53. Las ratios defunciones de párvulos/bautizados y total de defunciones/bautizados se han construido a partir de una muestra de 112 localidades (22 de Ávila, 23 de Burgos, 17 de Palencia, 17 de Zamora, 14 de Madrid y 19 de Guadalajara). El cociente defunciones de adultos/bautizados se ha calculado con una muestra de 242 localidades (38 de Ávila, 68 de Burgos, 40 de Palencia, 28 de Zamora, 18 de Madrid, 25 de Guadalajara, 14 de Albacete y 11 de Ciudad Real). 
El Cuadro 4 revela que la ratio defunciones/bautizados descendió de manera apreciable en las dos Castillas en la segunda mitad del siglo XVIII: un 11,4\% respecto a 1700-1749. Esta caída obedeció bastante más a la moderación de la mortalidad adulta que a la de la población infantil y juvenil: entre 1700-1749 y 1750-1799, el cociente óbitos de adultos/bautizados cayó un 16,1\% y la ratio párvulos fallecidos/ bautizados solo un $5,1 \%{ }^{54}$. Es bastante probable que este indicador infravalore algo el descenso de la mortalidad debido a que diversos indicios, que ahora no podemos detallar, apuntan a que el subregistro de enterramientos de párvulos disminuyó un poco en el transcurso del siglo XVIII.

Para valorar debidamente las cifras del Cuadro 4, además de tener presente el sesgo que la diversa calidad de los registros sacramentales en los distintos tramos del Setecientos pudiese introducir en la trayectoria de la ratio defunciones/ bautizados, conviene considerar la hipótesis de que los niveles de mortalidad hubiesen sido excepcionalmente elevados en las dos Castillas en la primera mitad del Setecientos. De ser así, el descenso de la ratio observado desde mediados del siglo podría implicar un mero retorno a los valores habituales de la mortalidad en el ámbito castellano en la Edad Moderna. No disponemos de toda la información necesaria para contrastar tal hipótesis, pero sí de la suficiente para no corroborarla, al menos por ahora: en la segunda mitad del siglo XVII, en las provincias de Ávila y Burgos, los niveles de mortalidad fueron superiores a los de la primera mitad del XVIII ${ }^{55}$. En consecuencia, la caída que hemos observado no fue un mero retorno a valores del pasado: la tasa bruta media anual de mortalidad del período 1750-1799 fue, probablemente, inferior a la registrada en cualquier otro período de cincuenta años de los siglos modernos.

El declive de la mortalidad no fue un fenómeno exclusivamente castellano en la España del Setecientos: en la región valenciana y en Cantabria, entre la primera y la segunda mitad de la centuria, la ratio total de defunciones/bautizados retrocedió un 7,5 y un $11,9 \%$, respectivamente ${ }^{56}$. Es bastante probable que fuesen claramente mayoritarios los territorios españoles en los que se moderó la mortalidad después de 1750, si bien tenemos dudas sobre lo acaecido, al efecto, en las regiones del sur peninsular donde el crecimiento demográfico fue débil en el Setecientos y las crisis de natalidad cobraron mayor magnitud en la segunda mitad del siglo, Extremadura y, sobre todo, Andalucía. Convendría que nuevas investigaciones aclarasen este asunto.

54. En casi todas las parroquias de Albacete y Ciudad Real, las defunciones de párvulos no se registraron de manera sistemática hasta las décadas centrales del siglo XVIII o fechas posteriores. De ahí que hayamos tenido que prescindir de ambas provincias en cuanto al estudio de la mortalidad de párvulos y de la mortalidad general en el siglo XVIII.

55. En la provincia de Ávila, la ratio defunciones/bautizados fue un 5\% más alta en 1650-1699 que en 1700-1749 (Cuervo, 2015: 299). En la de Burgos, entre esos mismos intervalos, el retroceso del citado cociente fue de un 10,1\% (ABARCA, 2015: 177).

56. Bernat (2013); ABARCA y LANZa (2013). 
En el Gráfico 3 hemos incluido las medias móviles de 9 años de las tasas de natalidad y mortalidad estimadas en ocho provincias de ambas Castillas entre 1750 y 1809.

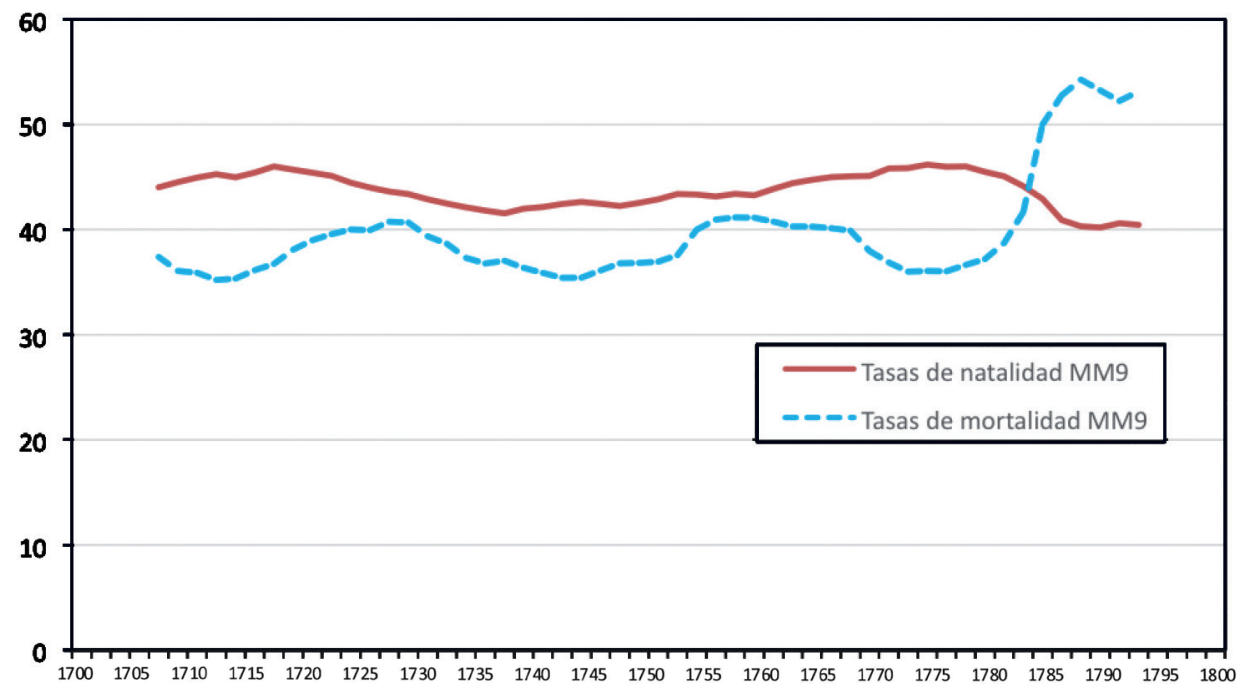

Gráfico 3. Tasas de natalidad y mortalidad estimadas en ocho provincias de las dos Castillas $^{57}, 1750-1809$ (medias móviles de 9 años, tantos por mil).

Fuentes: Las citadas en el Cuadro 4.

Puede apreciarse que la tasa de natalidad se mantuvo bastante estable en las dos mesetas en la segunda mitad del siglo XVIII: fue del 43,7\% en 1750-1774 y del 44,3\%o en 1775-1799. El valor máximo se registró en 1790-1798 (46,2\%o) y el mínimo en 1768-1776 (41,5\%o).

Los movimientos de la tasa de mortalidad alcanzaron, como era previsible, más intensidad, pero los últimos cincuenta años del Setecientos fueron un período de moderada inestabilidad de dicha variable. En las dos Castillas, la referida tasa alcanzó el 37,8\% en 1750-1774 y el 38,3\%o en 1775-1799. Ello implica que la magnitud del crecimiento vegetativo fue prácticamente la misma en el tercer y en el último cuarto del siglo XVIII. La máxima tasa de mortalidad correspondió al intervalo $1780-1788(41,2 \% \text { o })^{58}$ y la mínima al lapso $1753-1761(35,2 \%$ o).

57. Hemos partido de una muestra, en este caso, de 141 localidades: 22 de Ávila, 40 de Burgos, 15 de Palencia, 16 de Zamora, 14 de Madrid, 19 de Guadalajara, 9 de Ciudad Real y 6 de Albacete.

58. La sobremortalidad de 1786-1787 tuvo gran magnitud en algunas provincias de la Meseta meridional. PÉREZ MOREDA (1980 y 1984). 
Como hemos demostrado en distintos trabajos ${ }^{59}$, el descenso de la mortalidad general en las provincias castellanas durante la segunda mitad del siglo XVIII obedeció, fundamentalmente, a la moderación de la mortalidad ordinaria. Y resulta poco verosímil que ello pudiera haber acontecido sin una pequeña mejora económica, sobre todo en la dieta de la mayor parte de la población.

Aunque no fuese la protagonista principal de los cambios detectados, tiene interés examinar la trayectoria de la mortalidad catastrófica en el Setecientos. En el Cuadro 5 hemos incluido el número, la intensidad media y un índice agregado de crisis de mortalidad, en tramos de 25 y 50 años, de seis provincias castellanas ${ }^{60}$.

\begin{tabular}{|c|c|c|c|}
\hline PERÍODOS & NÚMERO & INTENSIDAD MEDIA (\%) & ÍNDICE AGREGADO (\%) \\
\hline $\mathbf{1 7 0 0 - 1 7 2 4}$ & 4 & 29,2 & 116,8 \\
\hline $\mathbf{1 7 2 5 - 1 7 4 9}$ & 7 & 33,8 & 236,7 \\
\hline $\mathbf{1 7 5 0 - 1 7 7 4}$ & 2 & 27,0 & 54,0 \\
\hline $\mathbf{1 7 7 5 - 1 7 9 9}$ & 1 & 20,7 & 20,7 \\
\hline $\mathbf{1 7 0 0 - 1 7 4 9}$ & 11 & 32,1 & 353,5 \\
\hline $\mathbf{1 7 5 0 - 1 7 9 9}$ & 3 & 24,9 & 74,7 \\
\hline
\end{tabular}

Cuadro 5. Número, intensidad media e índice agregado de las crisis de mortalidad en seis provincias castellanas, 1700-1799. Fuentes: Las citadas en el Cuadro 4.

Las cifras del Cuadro 5 revelan: 1) que la frecuencia de las crisis de mortalidad se redujo de manera bastante drástica en la segunda mitad del siglo XVIII (una cada 4,5 años antes de 1750 y una cada 16,7 después de esa fecha); 2) que la intensidad media de las mismas se moderó de modo significativo, descendiendo un 22,4\% de 1700-1749 a 1750-1799; 3) que la mortalidad catastrófica alcanzó su máxima dimensión en el segundo cuarto del Setecientos, lo que obedeció principalmente a las frecuentes y bruscas elevaciones del número de óbitos en la década de $1740^{61}$; y 4) que a escala regional tan solo se registró una crisis en el último cuarto de la centuria. En definitiva, la mortalidad extraordinaria retrocedió mucho en las

59. Llopis, Bernardos y Velasco (2015: 75-78); Abarca, Llopis, Sebastián, Bernardos y Velasco (2015: 127-139); Abarca, Llopis, Sánchez Salazar y Velasco (2016: 20-22 y 24-26).

60. A partir de una muestra de 105 localidades (22 abulenses, 23 burgalesas, 9 palentinas, 18 zamoranas, 14 madrileñas y 19 alcarreñas), hemos convertido los respectivos índices provinciales de defunciones en un índice regional de óbitos calculando el peso relativo que cada provincia tenía en 1787 en el conjunto de las seis. Para identificar y medir las crisis de mortalidad hemos empleado, de nuevo, la metodología de Del PANTA y Livi-BACCI (1977), pero, al tratarse de una agregación regional, hemos adoptado un umbral menor que el utilizado habitualmente en las monografías locales. Hemos supuesto la existencia de mortalidad catastrófica siempre que el número anual de defunciones superase en un $20 \%$ o más la correspondiente media truncada de 11 años.

61. Llopis, PÉrez Moreda y SEBAStián (2015). 
dos Castillas en la segunda mitad del siglo XVIII: el índice agregado que hemos calculado disminuyó nada menos que un 78,9\% entre $1700-1749$ y $1750-1799^{62}$. La clave de ese descenso tan intenso radicó en la reducción sustancial del número de episodios de mortalidad catastrófica y en la menor simultaneidad de los mismos en los distintos territorios castellanos ${ }^{63}$.

En suma, los índices de bautizados de España y de la mayor parte de sus regiones, la trayectoria de las crisis de natalidad y la moderación de la mortalidad, tanto de la ordinaria como de la catastrófica, apuntan con claridad a una significativa aceleración del crecimiento demográfico y a una mejora económica en un alto porcentaje de territorios peninsulares en la segunda mitad del siglo XVIII. Y esa dinámica demográfica vino marcada por el descenso de la mortalidad.

\subsection{Más producto agrario y más diversificado}

Los registros decimales integran la base documental más sólida disponible para estimar el crecimiento agrario en la España moderna. Constituyen, no obstante, un conjunto de fuentes dispares, intrincadas y heterogéneas que aportan datos parciales la mayoría de las veces y en pocas permiten una reconstrucción fidedigna de la composición, los niveles y la trayectoria del producto agrario. Las cifras que aportan suelen circunscribirse a las cuantías diezmadas de los frutos y esquilmos que entraban en el acervo común, el monto que debía repartirse entre los diversos partícipes en cada cilla ${ }^{64}$. En un alto porcentaje de casos, se consigue información suficiente sobre los diezmos mayores, los de cereales, pero solo datos fragmentarios o muy escasos acerca de los que gravitaban sobre otros productos ${ }^{65}$. Esta habitual asimetría informativa provoca, de un lado, que, en los espacios donde la producción agraria no cerealista creció más rápidamente que la cerealista desde mediados del siglo XVII (como las regiones mediterráneas), la estimación del producto agrario basada en la agregación de series decimales sesgue gravemente a la baja su crecimiento en el Setecientos ${ }^{66}$. De otro, en cualquier territorio, oculta la composición real de la

62. La mortalidad catastrófica también retrocedió en la segunda mitad del Setecientos, aunque de manera bastante más moderada, en Valencia, La Rioja y Mallorca (BERNAT y BADENES, 1988: 546; Lázaro y Gurría, 1989: 40; Moll, Segura y Suau, 1983: 178). En cambio, en Cantabria no se moderó (CATAlán y Lanza, 2015: 28) y en Guipúzcoa repuntó con fuerza debido a la virulencia de la crisis de 1794-1795 (PIQUERO, 1991: 144 y 147).

63. El estudio provincial de las crisis de mortalidad en las dos Castillas en Llopis y ABARCA (2014) y Llopis, Sebastián, Sánchez Salazar, Abarca y Velasco (2017).

64. Son muy numerosas las investigaciones que se han sustentado en las cantidades percibidas anualmente por uno de los partícipes principales.

65. Véanse, por ejemplo, los Libros de Vestuarios del cabildo de la catedral de Toledo; LÓPEZ Salazar y Martín Galán (1981); Sebastián, García Montero, Bernardos y Zafra (2008).

66. Como ha enfatizado para el País Valenciano ARDiT (1989: 394-395). 
producción agraria y sus cambios, manteniendo sumergidas fracciones más o menos relevantes de la misma, debidas a frutos y esquilmos ajenos a los granos.

Aparte de reconstruir el contenido íntegro del acervo común, lo que no siempre es fácil, un cálculo preciso del producto agrario requiere reunir información sobre las porciones de este que no entraban en aquel, las cuales podían alcanzar magnitudes en absoluto insignificantes y cuyo peso relativo varió en el transcurso del tiempo, de modo considerable quizá durante el siglo XVIII. Deben considerarse: 1) el producto de la casa mayor dezmera de cada término dezmatorio, cuando el Excusado dejó de ser un impuesto de cupo y pasó a ser administrado directamente por la Real Hacienda ${ }^{67}$; 2) los diezmos privativos, percibidos por los párrocos y otros eclesiásticos e instituciones; 3) la producción no sujeta total o parcialmente al pago del diezmo en fincas rústicas pertenecientes al clero regular y secular; 4) los frutos exentos del pago de dicho tributo o por los que se satisfacía, de hecho o de derecho, una tasa inferior al 10\% ${ }^{68}$; y, 5) por último, la parte defraudada por los cultivadores directos. En nuestra opinión, en el siglo XVIII, el producto agrario creció más que la masa decimal objeto de reparto entre los partícipes en el diezmo, sobre todo después de 1760, por tres motivos: porque el producto de la casa mayor dezmera no entró en el acervo común en varios tramos de las cuatro últimas décadas del Setecientos ${ }^{69}$; porque muchos párrocos lograron engrosar los diezmos privativos en detrimento de la masa decimal recogida en las tazmías, incluida en el acervo común ${ }^{70}$; y porque la defraudación en el pago del diezmo ya aumentó notablemente en las últimas décadas del siglo XVIII. Un ejemplo ilustra el argumento, incluso sin entrar en el tema del fraude. Si en las 21 localidades de Molina de Aragón citadas en la nota 70 se calcula el producto medio anual, en 1783-1787, a partir en exclusiva del acervo común, sin considerar

67. Fenómeno, desde 1761, con una vigencia distinta en cada obispado. En el de Burgo de Osma, por ejemplo, la casa mayor dezmera permaneció en manos de la Hacienda (y fuera del acervo común de cada cilla, por tanto) de 1761 a 1799 (PÉREz Romero, 2009: 76); en el de Cuenca, la administración directa por la Hacienda se extendió de 1761 a 1775, se volvió al sistema de concordias entre 1776 y 1793 y se retornó a la primera en 1794 (Archivo Capitular de Cuenca, Tazmías).

68. Un tratamiento in extenso de estas cuestiones en llopis, SEbastián, Abarca, Bernardos y VELASCO (2016: 16-33).

69. En los obispados de Ávila, Burgo de Osma, Burgos y Segovia, el Excusado suponía entre el 8,4 y el 10,6\% de la masa decimal (BArrio, 2004: 26; Cuervo, 2015: 394-396; Pérez Romero, 2009: 77; Abarca, 2015: 332; Llopis, Sebastián, Abarca, Bernardos y Velasco, 2016: 28). En una muestra de 43 localidades de La Mancha y la Serranía conquenses, en 1759, la casa excusada aportaba el 6,7\% al total de la cosecha de cereales (Archivo Capitular de Cuenca, Tazmías).

70. En una muestra de 47 dezmatorios segovianos, en 1771-1775, los diezmos privativos absorbieron el 1,7\% del diezmo completo de granos y el 5,4\% del de frutos y esquilmos ajenos a estos (Llopis, Sebastián, Abarca, Bernardos y Velasco, 2016: 29). En otra de las 21 localidades de Molina de Aragón, diócesis de Sigüenza, en 1783-1787, desviaban el 93\% del diezmo de avena, el 66\% del de leguminosas (garbanzos y bisaltos), el 31\% del de miel, el 59\% del de cera, el $80-84 \%$ del de pollos y lechones y el 94\% del de menudos en dinero (Archivo de la Catedral de Sigüenza, Encuesta de justificación de diezmos de 1788). 
la casa excusada, los diezmos privativos y las producciones no sujetas al pago de diezmos, en las cifras resultantes faltan el $17 \%$ de la producción de cereales; el 27,6\% de la de lana fina; el 8,6\% de la de lana zurca o basta; el 8,9\% de la de corderos; el 11,7\% de la de queso, y el 100\% de las de leguminosas, miel, cera, pollos, lechones y menudos en metálico ${ }^{71}$.

La historiografía insistió durante mucho tiempo en que un aumento sustancial de la defraudación en el pago del diezmo no tuvo lugar en la mayor parte de España hasta comienzos del siglo $\mathrm{XIX}^{72}$. Sin embargo, cada vez se acumulan más evidencias que apuntan a que dicho fenómeno data del último tercio del Setecientos ${ }^{73}$, aunque es indiscutible que se intensificó a raíz de las agudas crisis de subsistencias de 1803-1805 y del desplome del Estado absolutista tras la entrada de las tropas napoleónicas. ¿Qué factores propiciaron o desencadenaron un incremento considerable de la defraudación en el pago del diezmo en el último tercio del siglo XVIII? Resistencias a la entrega de este tributo siempre había habido, pero los cultivadores se sentían atenazados por el miedo a ser excomulgados; el fraude no debió de superar un cierto umbral hasta que el temor a semejante condena no se mitigó, al hilo de una incipiente secularización de la sociedad española en la segunda mitad del siglo XVIII ${ }^{74}$ y al de algunos cambios en los comportamientos colectivos, visibles en la misma época. Sobre estos últimos, existe gran distancia entre la habitual resistencia campesina a pagar diezmos que se observa en un documento leonés de $1711^{75}$ y la intención de defraudación generalizada que se aprecia en otro alcarreño de $1788^{76}$. Dejando a un lado el aspecto religioso, la principal consecuencia civil de la declaración de "público descomulgado", el apartamiento cual apestado del

71. Reducidas a dinero todas estas producciones, ello supondría la ausencia del 13,9\% del valor del producto agrario; Archivo de la Catedral de Sigüenza, Encuesta de justificación de diezmos de 1788.

72. CANALES (1982).

73. ARDIT (1989) aportó pruebas al respecto hace ya tiempo.

74. HERR (1979).

75. Un apercibimiento de excomunión de 1711, expedido por el provisor y vicario general de la diócesis de León a favor del monasterio de Otero de las Dueñas, amenaza con la citada pena a ciertos vecinos de Villalba de la Loma, Villacíntor y Grajalejo si no se enmiendan y abonan los diezmos "según toca, por medidas corrientes y no por medidas rasas, como han hecho, siendo perjudicado en mucha cantidad de grano el dicho convento». La advertencia también concierne a "diferentes personas eclesiásticas, que se han quedado por diezmar de lo que labran». Archivo Histórico Diocesano de León, Fondo M. Bravo, 51.

76. A la pregunta 10 ( ¿ ¿Si se alzan los montones de las eras sin llamar al colector de diezmos, que según Constitución debe hallarse presente?») de la Encuesta de justificación de diezmos de 1788, ordenada por el provisor y vicario general del obispado de Sigüenza, la respuesta mayoritaria de los pueblos consistió en que sí avisaban al colector para que viese medir el diezmo, pero todos a una, el mismo día y hora; aquel no podía controlar la operación "porque es imposible que a un mismo tiempo pueda hallarse presente al levante de los montones de todos los cosecheros, y si no acude, meten el grano en sus casas y luego le pagan allí». Archivo de la Catedral de Sigüenza, Encuesta de justificación de diezmos de 1788 . 
condenado de la comunidad vecinal ${ }^{77}$, debió de perder virtualidad al acentuarse el carácter colectivo de la transgresión. Además, el recrudecimiento de las pugnas entre los eclesiásticos (entre el clero secular y el regular; entre el alto y el bajo clero secular) por el reparto de la masa decimal, claramente visible en los documentos catedralicios luego de $1760^{78}$, generó un contexto favorable para que los productores directos se atreviesen a incumplir de modo cada vez más flagrante la obligación de satisfacer íntegramente los diezmos. Muchos párrocos leyeron acertadamente que una parte del crecimiento agrario que estaba aconteciendo (en nada ajena al interés de los cultivadores por eludir el pago de diezmos) discurría por la vía de la diversificación de los cultivos y que ello, si se obviaba en todo o en parte en las tazmías, facilitaba el aumento de su cuota decimal frente al resto de partícipes; en muchas villas y aldeas, seguramente de modo implícito, se concertaron acuerdos ilícitos a costa de terceros: los curas aceptaron que los productores directos pagasen con menos rigor los diezmos correspondientes y, a cambio, estos silenciaron el aumento unilateral de los diezmos privativos del clero local. Esta suerte de colusión tácita es la que explica el permisivo comportamiento de los párrocos con prácticas tan transparentes en su intención como las dirigidas a eludir la presencia de los colectores en las eras en Molina de Aragón en la década de 1780, ya descritas, y la ausencia de terceros en numerosos dezmatorios del obispado de Burgos, hacia 1775, a la hora de levantar el grano aventado $^{79}$; a su vez, permite entender la creciente opacidad que se aprecia en muchos libros de tazmías desde mediados del siglo XVIII, en especial respecto a los componentes del producto agrario no cerealista. Los cabildos catedralicios acabaron reaccionando, pero sin la colaboración del clero local era difícil que saliesen victoriosos de semejante pugna.

En la diócesis de Sigüenza los ejemplos son abundantes, pero nos limitaremos a uno, el de la localidad alcarreña de Trillo. En 1752, la masa decimal de esta población la componían los diezmos granados (de trigo, cebada y avena), los de uva y los menudos (de garbanzos, alubias, olivas o aceite, cáñamo, cañamones, lana, corderos, cochinillos, pollos, alazor, almortas, miel, cera, ajos, berzas, nabos, cebollas y nueces ${ }^{80}$. En el libro de tazmías iniciado en 1753, los frutos y esquilmos citados siguieron incluyéndose hasta 1764; en 1765, no obstante, los diezmos menudos desaparecieron de los registros y, en 1766, ocurrió

77. "Y mandamos a los vecinos y moradores de los tales lugares que no participen con los sobredichos rebeldes en comer ni en beber, en andar ni en estar, ni les den sal, ni fuego, ni agua, ni les guarden sus ganados, ni les paguen las deudas que les deban». Apercibimiento de excomunión de 1711, Archivo Histórico Diocesano de León, Fondo M. Bravo, 51.

78. Los interrogatorios, pesquisas, pleitos y recopilaciones sobre irregularidades y fraudes en el pago de los diezmos se tornan cada vez más abundantes desde 1760; basta examinar los catálogos de distintos archivos catedralicios de la Corona de Castilla para comprobarlo.

79. ABARCA (2015: 302-304).

80. Certificación de diezmos inserta en las Respuestas Generales del Catastro de Ensenada, productos y cantidades regulados por el quinquenio 1747-1751. El alazor es un sustitutivo del azafrán. 
otro tanto con los de uva: desde ese año hasta 1786, las anotaciones atañen tan solo a los diezmos granados ${ }^{81}$. En las décadas de 1770 y 1780, esta forma de proceder se había generalizado en el obispado; así lo prueba el despacho del provisor y vicario general del mismo dado en 1785, mandado copiar en el libro de tazmías de Trillo y dirigido «a los señores curas, vicarios, ecónomos y tenientes» del arciprestazgo de Cifuentes ${ }^{82}$. En él se indica que "los curas no forman las tazmías que llaman de marzo, las de menudos y mencales que por él y meses siguientes se acostumbran a dezmar", que solo dan noticias "de priesa y mal formadas, contra lo dispuesto en las constituciones sinodales, el día que pasan los mayordomos pontificales a hacer el diezmo de lana y corderos». De esta "Confusión y falta de tazmías y diezmos menudos han resultado infinidad de pleitos decimales, intrusiones y otros perjuicios». Por ello, el provisor ordena a curas y párrocos, so pena de excomunión mayor, que formen las referidas tazmías «a lo menos quince días antes que llegue el que se haga el diezmo de lanas y corderos, compeliendo con todo rigor a los feligreses para que hagan las declaraciones competentes y las ejecuten con arreglo al formulario impreso, librado el año de 1690»83. Y añade, "cuiden y celen de evitar cualquier intrusión particularmente en los diezmos de aquellas semillas que de pocos años a esta parte se han principiado a sembrar ${ }^{84}$. La admonición, sin embargo, solo se atendió dos años después, en 1787, cuando en las tazmías de Trillo, junto a los diezmos granados, volvieron a aparecer los de uva y los menudos. Es entonces cuando un velo se descorre y aparecen veinticinco frutos y esquilmos ajenos a los cereales, algunos, como los incluidos en el Cuadro 6, en cuantías bastante más elevadas que las registradas hacia 1752.

81. Con la excepción de algunos apuntes sobre diezmos de uva en 1767 y 1777 , y de uva, corderos y lana de 1779. Archivo Histórico Diocesano de Sigüenza, Trillo, Libros de Tazmías (1753-1768 y 1768-1797).

82. Se envió a todos los arciprestazgos de la diócesis. Véase, por ejemplo, Archivo Histórico Diocesano de Sigüenza, Hijes, Libro de Tazmías (1760-1803).

83. Este, incluido en los libros de tazmías de cada parroquia, constituía una guía ágil y completa para el cobro de diezmos, concretando lo previsto en las Constituciones Sinodales de 1660. Contemplaba, entre otras cosas, la obligación de sumar las cuantías anuales de cada especie diezmadas por los productores; una de las formas de dificultar el control de los registros por los eventuales visitadores del cabildo era, precisamente, omitir dichas sumas e incluir largos y prolijos listados de cosecheros y cantidades individuales. Véase el ejemplo de Ledanca, cuyos curas seguían sin incluirlas en la década de 1780, pese a la advertencia que habían recibido, al respecto, en 1747. Archivo Histórico Diocesano de Sigüenza, Ledanca, Libro de Tazmías (1768-1795).

84. Sin perjuicio de los clérigos a quienes se han reconocido como privativos ciertos diezmos, "pero sólo de aquellas especies en que estén en posesión, y con la obligación de que expresen estarlo con la mayor claridad y distinción». Archivo Histórico Diocesano de Sigüenza, Trillo, Libro de Tazmías (1768-1797). 


\begin{tabular}{|c|c|c|c|c|}
\hline PERÍODOS & $\begin{array}{c}\text { UVA } \\
\text { (ARROBAS) }\end{array}$ & $\begin{array}{c}\text { CÁÑAMO } \\
\text { (ARROBAS) }\end{array}$ & $\begin{array}{c}\text { LEGUMINOSAS } \\
\text { (ARROBAS) }\end{array}$ & $\begin{array}{c}\text { PATATAS } \\
\text { (ARROBAS) }\end{array}$ \\
\hline $\mathbf{1 7 4 7 - 1 7 5 1}$ & 522,0 & 7,3 & 5,1 & 0,0 \\
\hline $\mathbf{1 7 8 7 - 1 7 9 1}$ & $1.845,0$ & 13,0 & 13,0 & 6,4 \\
\hline $\mathbf{1 7 9 3 - 1 7 9 7}$ & $1.072,0$ & 17,0 & 23,6 & 146,0 \\
\hline
\end{tabular}

Cuadro 6. Diezmos de cuatro especies no cerealistas en Trillo, Guadalajara, en la segunda mitad del siglo XVIII (medias anuales por quinquenio). Fuentes: Respuestas Generales del Catastro de Ensenada (pares.mcu.es/Catastro) y Archivo Histórico Diocesano de Sigüenza, Trillo, Libro del Tazmías (1768-1797).

Es evidente que las cifras del Cuadro 6 indican crecimiento productivo, notable en los casos de la uva, el cáñamo y las leguminosas (judías y garbanzos), espectacular en el de la patata ${ }^{85}$, pero, ¿hasta qué punto? Es sabido que los cultivadores procuraban no pagar diezmo alguno por los cultivos nuevos y, considerando lo dicho hasta aquí, es muy posible que, en Salamanca como en Guadalajara, las patatas solo apareciesen en los registros decimales cuando su cultivo ya hubiese adquirido cierta entidad. Es probable, además, que la tasa efectiva satisfecha en su caso por los cosecheros fuese inferior al 10\% y, sobre todo, que el área cultivada de patatas resultase bastante más amplia que la que cabe inferir de la documentación decimal ${ }^{86}$. Como hemos visto, las posibilidades de que actividades agrícolas como esta permaneciesen en la penumbra en el último tercio del siglo XVIII no eran escasas. Respecto a los frutos y esquilmos tradicionales, distintos de los granos, si el diezmo nunca se pagó con tanto rigor como en el caso de estos, es factible que, al aflojar la presión del clero local, cuyos diezmos privativos se nutrían, sobre todo, de tales productos, los cultivadores ensanchasen el margen existente para elevar los niveles de defraudación. Por todo ello, los aumentos que se observan en el Cuadro 6 deben reputarse como mínimos.

Pero la defraudación en el pago del diezmo también progresó por vías ajenas a la diversificación de cultivos en las cuatro últimas décadas del Setecientos. En cuanto a los cereales, fueron numerosos los cultivadores directos que empezaron a descontar la simiente y otros gastos del producto bruto que teóricamente gravaba

85. El de Trillo no es un caso aislado en el ámbito alcarreño; en Ledanca, el cultivo de patatas se cita por vez primera en 1789. Archivo Histórico Diocesano de Sigüenza, Ledanca, Libro de Tazmías (1768-1795). Tampoco estos ejemplos son especialmente precoces en el interior castellano: en 13 pueblos salmantinos hemos podido estimar una producción anual superior a las 3.600 arrobas en el quinquenio 1771-1775. Archivo de la Catedral de Salamanca, Averiguaciones de rentas para la contribución de Subsidio y Excusado.

86. Resulta sospechoso que, en tres de los cinco años del quinquenio 1793-1797, la cantidad diezmada de patatas en Trillo sea exactamente la misma, 150 arrobas. Archivo Histórico Diocesano de Sigüenza, Trillo, Libro de Tazmías (1768-1797). 
el diezmo ${ }^{87}$. Así se expresaba el agente general del arzobispado de Toledo en un escrito remitido al contador en abril de 1806, para que este, si lo creía oportuno, lo elevase al cardenal, a fin de que este último implorase la protección del monarca: «Si mal se diezmaba antes y aún peor se diezma ahora, y si antes se defraudaba el diezmo con la deducción de la simiente y demás expensas, y por la otra multitud de medios que quedan intimados, en el día se niegan ya en muchos pueblos abiertamente a pagarle, por la escasez de cosechas y otros pretextos ${ }^{88}$. Teniendo en cuenta que era minoritaria, en el interior castellano, la porción del terrazgo cerealista en la que el rendimiento por unidad de semilla sembrada superaba la ratio 1 a 5, solo la deducción de la simiente suponía un fraude en el pago de los diezmos mayores de gran entidad, superior al 20\%. Lógicamente, ni todos los campesinos se sumaron a semejantes prácticas al mismo tiempo, ni todos defraudaron en igual medida, pero, como ha podido observarse, son numerosos los testimonios que apuntan al agravamiento y a la generalización del problema durante el último tercio del siglo XVIII.

En suma, por distintos motivos entre los que sobresale el notable incremento de la defraudación, las series de diezmos publicadas ${ }^{89}$ infravaloran el crecimiento del producto agrario español en la segunda mitad del siglo XVIII en un porcentaje importante, probablemente superior al 15\%.

Pese a este relevante problema de infravaloración, son muchas las publicaciones recientes (y alguna no tanto) que apuntan a que el producto agrario por persona creció en la España del Setecientos.

Las cifras decimales gallegas, cántabras y vascas permiten mantener que el producto agrario per cápita aumentó en la España húmeda, durante el Setecientos, a una tasa no inferior al $0,1 \%{ }^{90}$. En La Rioja, de $1730-1739$ a $1790-1799$, la ratio producto cerealista/bautizados aumentó un 22,3\%; la ratio producción de vino/bautizados un $8,3 \%$, y la ratio producción de leguminosas, forrajes, vino y aceite/bautizados creció aún más que las dos precedentes ${ }^{91}$. En Aragón, los índices de volumen elaborados por Latorre sugieren una pequeña elevación del producto agrario por habitante entre finales de los siglos XVII y XVIII. Teniendo en cuenta que las tierras bajas, las más dinámicas, están infrarrepresentadas en la muestra de localidades utilizada, al igual

87. Las respuestas de algunos pueblos de la Alcarria a la Encuesta de 1788 sugieren esta posibilidad. Por ejemplo, la de Sotodosos ("Antes de levantar los montones de las eras avisan al colector de ellos y no acudiendo a tiempo, los levantan en parte, aunque no en el todo, hasta que satisfacen el diezmo que han adeudado») y la de Saelices de la Sal (Antes de levantar los montones de las eras avisan al colector de los diezmos, y si no acude con tiempo por ser dificultoso poderlo hacer a todos los montones, miden su cosecha y según esta dejan lo correspondiente al diezmo»). Archivo de la Catedral de Sigüenza, Encuesta de justificación de diezmos de 1788.

88. Archivo Histórico Nacional, Consejos, leg. 3223, exp. 29, ff. 2v.-3r.

89. Nosotros mismos somos responsables de algunas; véase, por ejemplo, SEBASTIÁn (1991).

90. Eiras (1982); LANZA (2010); FERnÁNDEZ DE Pinedo y GARCía ZÚÑIGa (2008).

91. Catalán (2008 y 2018). 
que productos como el aceite y el azafrán, de valor relativamente alto por unidad de volumen, resulta muy verosímil que el alza del producto agrario per cápita fuese algo mayor que la apuntada92. En Mallorca, el fenómeno más llamativo en el Setecientos radicó en una notable diversificación de cultivos: leguminosas, viñedo, almendras, higos, cáñamo y algarrobas ganaron terreno a costa de los cereales. El olivar, muy importante en la isla, alcanzó su cénit antes de $1790^{93}$. No resulta creíble que semejante diversificación, que suponía cierta intensificación del uso del suelo, no comportase un incremento del producto agrario por habitante. En Cataluña, según Durán y Feliu, el PIB per cápita creció un 30,6\% entre 1686-1695 y 1786-1795. Ellos mismos consideran, no obstante, que ese porcentaje infravalora el crecimiento económico del Principado, debido al menor rigor con que se efectuó el pago de los derechos señoriales a finales del siglo XVIII y al insuficiente peso otorgado al producto urbano, más dinámico que el rural, en el último intervalo comparado94.

Por su parte, las cifras andaluzas y castellano-manchegas extraídas de fuentes catedralicias, que combinan la virtud de abarcar áreas enormes con el inconveniente de basarse fundamentalmente en series de arrendamientos de diez$\operatorname{mos}^{95}$, lo que añade más problemas a los ya descritos, no invitan al optimismo. Las correspondientes a Andalucía occidental indican que el producto agrario por persona creció algo menos de un 10\% en el Setecientos, lo que sería insuficiente para que aquel recobrase en la década de 1790 el nivel del intervalo 1585-1594. Las concernientes a Castilla-La Mancha, pese al escaso dinamismo demográfico, ofrecen un panorama incluso más desolador: práctico estancamiento de la citada variable entre finales de los siglos XVII y XVIII, y niveles hacia 1790 un $30 \%$ inferiores, todavía, a los de 1587-1595 ${ }^{96}$. Acerca de Andalucía occidental, nada nuevo podemos añadir a día de hoy. No obstante, en cuanto a tierras castellanas, trabajos y cálculos más recientes que el citado texto de 2008 aportan tres elementos de reflexión y sugieren que el panorama trazado en este era exageradamente adverso. Uno, para Albacete y Ciudad Real, al menos, existen evidencias suficientes como para afirmar que la mortalidad conoció un descenso significativo entre la primera y la segunda mitad del Setecientos ${ }^{97}$. Dos, en la Submeseta norte, la cuidadosa reconstrucción de la producción agraria a partir de fuentes decimales de singular calidad en una amplia muestra de localidades

92. LATORRE (2010).

93. JOVER Y MANERA (2009).

94. Durán y FELIU (2008).

95. Los Libros de Mayordomía del cabildo de la catedral de Sevilla y los Libros de Vestuarios del de la catedral de Toledo.

96. Llopis y GonZÁlez Mariscal (2010: 24); Sebastián, García Montero, Bernardos y Zafra (2008: 18).

97. Pese a que las deficiencias en el registro de óbitos de párvulos impiden ofrecer cifras precisas sobre la mortalidad total, la de adultos se redujo un 13,1\%, en conjunto, entre 1700-1749 y 1750 1799. Abarca, Llopis, Sebastián, Bernardos y Velasco (2015: 119-127). 
de cuatro provincias (Ávila, Burgos, Salamanca y Segovia), en 1588-1592 y 17711775, muestra que, hacia 1773 , no solo se habían recuperado los niveles de producto agrario por habitante de 1590, sino que, en conjunto, se habían superado $^{98}$. Y tres, que, según una muestra de 60 localidades, en dos comarcas conquenses, la Mancha y la Serranía, la producción cerealista por habitante, al menos, creció con claridad en el último tramo del siglo XVIII: un 14,8\% entre $1771-1775$ y $1790-1794^{99}$.

En suma, a la luz de las cifras decimales, del tipo y la magnitud de los problemas que entraña su uso para estimar el crecimiento del sector primario en el Setecientos, y teniendo en cuenta que, por más que se empleen las de mayor calidad y se extreme el cuidado en los cálculos, la infravaloración subsiste, aunque se minimice, consideramos muy verosímil que el producto agrario por persona creciese en España, en el siglo XVIII, a una tasa media anual acumulativa superior al 0,1\%.

\subsection{El crecimiento aún mayor del producto no agrario}

Son diversos los indicios de que el producto no agrario creció más que el del sector primario en la España del Setecientos, sobre todo en su segunda mitad: la trayectoria de la tasa de urbanización, la expansión de las actividades no agrarias en el mundo rural y el notable incremento del comercio interior y exterior.

La medición precisa de la tasa de urbanización en España, sobre todo en fechas anteriores a las postreras del siglo XVIII, no es posible debido a la falta de censos de población completos y fiables y a la considerable importancia que las agrociudades tenían en su mitad meridional ${ }^{100}$. Ahora bien, nadie pone en duda que la población urbana aumentó más que la rural en la España del Setecientos y que el diferencial de crecimiento entre ambas fue mayor después de mediados de la centuria que antes de 1750. Así, por ejemplo, Álvarez-Nogal y Prados estiman que la tasa de urbanización era del 11,1\% en 1700, del 13,5\% en 1750 y del $17,4 \%$ en $1800^{101}$. Es cierto que el avance fue mucho más intenso en las regiones mediterráneas, pero el aumento del peso relativo de la población de las ciudades también fue notable en ambas Castillas.

98. En valor, el producto cerealista por persona era un 4,8\% más alto hacia 1773 que hacia 1590, y el no cerealista, un 10,2\%. Llopis, Sebastín, Abarca, Bernardos y Velasco (2016: 30-33).

99. Llaman la atención los niveles similares que, en términos físicos, alcanzaba dicho producto cerealista por persona en 1771-1775 en Cuenca (14,8 fanegas de grano/año) y en el conjunto de Ávila, Burgos, Salamanca y Segovia $(15,3)$. Archivo Capitular de Cuenca, Tazmías, y Llopis, Sebastián, Abarca, Bernardos y Velasco (2016: 30-32).

100. LLOPIS Y GONZÁLEZ MARISCAL (2006).

101. Estimación que efectúan considerando urbes a los núcleos con más de 5.000 habitantes, tras excluir a la población dedicada al sector primario que vivía en los mismos (Álvarez-NogAL y PRADOS, 2013: 14). 
España, sobre todo después de 1750, no fue completamente ajena a la llamada revolución industrios $a^{102}$, si bien este fenómeno, en relación a lo acontecido en los países de Europa noroccidental, fue más tardío, tuvo una difusión y una magnitud menores y obedeció a móviles distintos. En la mayor parte de España, la mayor laboriosidad de las familias rurales fue bastante más impulsada por el fuerte descenso de los salarios reales ${ }^{103}$, el alza de la renta de la tierra ${ }^{104}$ y la tendencia a la reducción del tamaño de sus explotaciones que por sus deseos de acceder al consumo de nuevos y mejores bienes y servicios. En realidad, España no estuvo fuera de la norma europea: en la mayor parte del continente, como ha insistido Malanima, los campesinos se tornaron más industriosos en el Setecientos porque no tuvieron más remedio ${ }^{105}$. Quizá sea preciso añadir un matiz a esa apreciación: las familias rurales pudieron intensificar el uso de su fuerza de trabajo y obtener mayores ingresos complementarios gracias a que los niveles de actividad económica y los mercados se estaban expandiendo.

En España, la pequeña revolución industriosa de la segunda mitad del siglo XVIII entrañó dos cambios relevantes. Uno, el aplastante predominio de la agricultura en el mundo rural se mitigó algo. Y, dos, el peso de la mujer en las actividades productivas y el mercado de trabajo aumentó porque muchas familias hubieron de reestructurar sus tareas laborales debido a la emigración de varones jóvenes y a la insuficiencia de los ingresos aportados por sus explotaciones agrarias para asegurar su subsistencia y reproducción ${ }^{106}$.

En Cataluña y Valencia, aparte del desarrollo de la viticultura y de otros cultivos arbustivos y arbóreos ${ }^{107}$, la expansión manufacturera, la del comercio, la del transporte y la de otros servicios impulsaron la intensificación del uso del factor trabajo en el siglo XVIII ${ }^{108}$.

En Galicia, Cantabria y el País Vasco también se hallan pruebas de una mayor laboriosidad. En tierras gallegas, el sistema agrario venía transformándose desde el segundo cuarto del siglo XVII. Si, al principio, los mayores cambios acaecieron en los valles litorales y prelitorales, en la segunda mitad del Setecientos fueron las comarcas interiores las que ganaron protagonismo; en ellas, el maíz y, sobre todo, la patata, progresaron, y el ganado estabulado ganó peso relativo gracias al incremento del área de prados y a la difusión del cultivo de nabos. En el conjunto

102. De VRIES (1994 y 2009: 57-223).

103. Feliu (1991, vol. II); Reher y Ballesteros (1993); MORENo LÁzAro (2002); Llopis y García MONTERO (2011); LÓPEZ LOSA y PIQUERO (2016).

104. ANES (1970: 273-291); GARCía SANZ (1977: 296-310); ÁLvarez VÁzQuEz (1987: 76-96); SEBASTIÁN (1990); TELLO (1992 y 1995).

105. Malanima (2009: 238).

106. SARASÚA (2009 y 2018).

107. VALLS (1996: 93-137, y 2004: 103-200); ARDIT (2007: 43-46 y 49-50).

108. Torras (1994 y 2007: 170-182); Benaul (1992); NADAl y Benaul (coords.) (2003); Pérez SARRIÓN (2012: 399-434). 
de la región, además de las novedades en el sistema agrario y del aumento del espacio labrado, la ampliación de los flujos migratorios estacionales y temporales, la expansión del comercio y del transporte y, sobre todo, el auge de la industria rural, en especial, de la producción de lienzos y de la actividad conservera, contribuyeron a la intensificación del uso del factor trabajo en los núcleos rurales. Galicia constituye el paradigma de cómo la fuerte presión de la población sobre los recursos, en el seno de una sociedad muy tradicional en la que el peso del mundo urbano era exiguo, acabó induciendo un incremento de la laboriosidad y relevantes mudanzas económicas ${ }^{109}$. En Cantabria, fueron el comercio, el transporte, las manufacturas y la construcción las actividades más dinámicas en el Setecientos. En el País Vasco, el avance de las manufacturas fue modesto, siendo el comercio el subsector de su economía que más creció en el siglo XVIII ${ }^{110}$.

En la España interior, las evidencias sobre cambios en la intensidad del uso del factor trabajo son menos contundentes y abundantes. No obstante, numerosas familias rurales, empujadas más por la necesidad de enjugar sus deficitarios presupuestos que por el deseo de acceder a cestas de consumo más variadas y ricas, tendieron a trabajar más y a diversificar en alguna medida sus actividades productivas, incrementando su participación en la producción de manufacturas, en el transporte, en el comercio al por menor y en el suministro de pequeños servicios. En lo concerniente a la actividad manufacturera, existen bastantes ejemplos del importante desarrollo de la misma en distintos espacios rurales en el Setecientos: el hilado de la lana que numerosas mujeres alcarreñas realizaban para la Real Fábrica de Paños de Guadalajara; el gran número y la diversidad de experiencias textiles en la región andaluza en la segunda mitad del siglo; el desarrollo pañero de algunos núcleos cacereños (Torrejoncillo, Casatejada y Hervás), de Palencia (Astudillo, Amusco, Fuentes de Nava y Prádanos de Ojeda) y de Salamanca (Béjar); el auge de la harinería en el norte de Castilla y León ${ }^{111}$, y la singular difusión, hacia 1784, del hilado y del tejido del lino en varias comarcas leonesas (las Montañas septentrionales, la Maragatería, el Páramo, la Tierra de León, los Campos leoneses) y el norte de Tierra de Campos ${ }^{112}$. Probablemente, aún fue más importante la mano de obra rural movilizada por el desarrollo del comercio y de los transportes. Sin duda, la segunda mitad del siglo XVIII y la primera del XIX constituyeron la edad de oro de la carretería y la arriería ${ }^{113}$. Aunque, en el interior peninsular, la intensificación

109. SAAVEDRA (1985: 180-291); CARMONA (1990: 65-150); CARMONA y NADAL (2005: 4-58).

110. LANZA (2010: 312); FERNÁNDEZ DE PINEDO y GARCÍA ZÚÑIGA (2008).

111. GonZÁlez ENCISO (1980: 394 y 472-473); PAREjo (1987: 129-141); LLOPIS (1993: 49-52); HeRNÁNDEZ GARCía (2010: 27-38); Ros (1999); MORENO LÁZARO (1997).

112. En una muestra de 647 núcleos poblados, que albergaban 127.345 personas en 1787, los dos tercios de las localidades y de los habitantes del antiguo y muy extenso partido de León que registra el censo de Floridablanca, se producían anualmente más de 590.000 varas de lienzo, amén de cerca de 160.000 de paño, a mediados del decenio de 1780. SEBASTIÁn (2004: 161-163 y 176-177).

113. Sobre los arrieros segovianos y maragatos, BERnARDos (2003) y RuBIO (1995). 
del uso de la mano de obra no obedeció fundamentalmente a incentivos mercantiles, sí parece haber tenido un mayor alcance cerca de las ciudades, sobre todo de las más importantes, y de las principales rutas comerciales.

Tres argumentos nos inducen a considerar bastante probable un incremento de la tasa de actividad femenina en la segunda mitad del siglo XVIII. Uno, la caída del salario real del breadwiner ${ }^{114}$ hubo de obligar a una mayor movilización de los recursos laborales de numerosas familias; dos, la notable expansión en ese período de algunos sectores manufactureros, sobre todo del textil, en los que el trabajo de las mujeres era muy relevante; y tres, la feminización del servicio doméstico que se venía registrando en el Setecientos, al menos en Madrid ${ }^{115}$. El trabajo de las mujeres ha dejado pocas huellas en las fuentes documentales del Setecientos, situándose en una zona aún más oscura que el avance en la diversificación de los cultivos, la creciente defraudación en el pago del diezmo o la difusión de actividades no agrarias en el mundo rural. En los casos en que el velo se descorre, pese a que no pueden considerarse representativos, sorprende la magnitud de la contribución laboral femenina. Una muestra de pueblos palentinos arroja, entre la población de 10 a 60 años, unas tasas de actividad del $86 \%$ en los varones y del $77 \%$ en las mujeres a mediados del siglo XVIII ${ }^{116}$. En la ciudad de Madrid, se ha estimado que la tasa de actividad femenina superaba el $50 \%$ en la segunda mitad de dicha centuria ${ }^{117}$.

Las evidencias disponibles sobre la trayectoria del comercio interior y exterior apuntan a que los tráficos se expandieron más velozmente que el producto agrario en la España del Setecientos. Es más, según Pérez Sarrión, los dos protagonistas centrales del cambio económico que se registraría por entonces serían ciertos grupos sociales dedicados a activar y articular el mercado interior, organizados en redes mercantiles, y el Estado ${ }^{118}$. Contamos con indicios significativos acerca de los progresos habidos en la integración de los mercados españoles de bienes. Aunque los costes de transacción se estaban reduciendo más lentamente en el comercio interior que en el transatlántico, el diferencial de precios del bacalao entre Bilbao y Toledo se redujo a una tasa anual del 0,24\% entre 1650 y 1800. También hubo avances en la integración de los mercados de cereales, si bien se registró alguna involución, quizá motivada por el aumento del peso relativo del comercio exterior de granos, en el grado de interrelación de los precios entre varios puertos

114. Moreno LÁZARO (2002: 94-105); Feliu (2004: vol. 1, 159); LLOPIS y GARCía MONTERO (2011: 304-307); LÓPEZ LoSA y PiQuero (2016: 15-19).

115. SARASÚA (1994).

116. HERNÁNDEZ GARCÍA (2013a y 2013b: 108-111).

117. López BARAHONA (2016: 45) indica que, hacia 1787, estaban empleadas o buscaban trabajo en torno a 25-30.000 mujeres en Madrid, cerca del 60\% de las potencialmente activas por entonces. El trabajo infantil también queda en la penumbra; véanse SARASÚa (2013) y HERNÁNDEZ GARCía (2013b).

118. PÉREZ SARRIÓN (2012: 27). 
mediterráneos y otras plazas en ciertos lapsos de la segunda mitad del siglo XVIII ${ }^{119}$. Si bien carecemos de estudios cuantitativos sobre los tejidos, es indudable que las redes mercantiles de franceses y catalanes ayudaron a activar su comercio a larga distancia y a integrar sus mercados, sobre todo entre 1750 y $1800^{120}$. El desarrollo de los tráficos, sin embargo, afrontó problemas difíciles de superar: aparte de la orografía y las deficientes infraestructuras viarias, el poder fiscal que aún poseían las ciudades y la subsiguiente heterogeneidad territorial en materia tributaria impidieron que la integración de los mercados superase cierto punto ${ }^{121}$. Pese a ello, los avances al respecto fueron considerables.

La política económica de los gobiernos ilustrados debe protagonizar un último apunte pues, más allá de sus motivos fiscales y de sus escasos resultados en ciertos aspectos, contribuyó a que el orden de cosas cambiase, desde 1765, al menos en tres aspectos relevantes para la agricultura y para el conjunto de la economía española: la abolición de la tasa y la liberalización del comercio de granos, la moderación de los privilegios de la Mesta y, con menos rotundidad porque tuvo efectos distintos en cada demarcación según la diferente capacidad de resistencia de las oligarquías locales, los repartos de tierras municipales y el acceso a estas de los pequeños cultivadores ${ }^{122}$.

En síntesis, todo apunta a que las actividades secundarias y terciarias crecieron más velozmente que las primarias en la España del Setecientos, sobre todo después de 1750. Si el producto agrario por habitante se hubiese incrementado durante la centuria a una tasa no inferior al 0,1\%, fenómeno bastante verosímil, el PIB per cápita habría aumentado a una tasa, cuando menos, próxima al 0,15\%. El balance económico de nuestro país había sido bastante negativo entre 1580 y 1700, de modo que una parte del avance del siglo XVIII se consumió en recobrar posiciones perdidas tiempo atrás; pero, luego de que el interior coronase su recuperación hacia 1750 , el crecimiento neto enseñoreó la segunda mitad de la centuria.

4. ¿POR QUÉ MEJORARON LAS COSAS EN EL INTERIOR PENINSULAR ENTRE 1750 Y 1800 ?

Entre finales del siglo XVI y mediados del XVIII, la trayectoria económica de las distintas regiones españolas fue bastante dispar. Primero, la depresión del Seiscientos tuvo una intensidad y una duración muy diferentes en los diversos territorios. Luego, la cronología, la naturaleza, el vigor y la continuidad de la recuperación posterior fueron muy distintos en la España septentrional, en la levantina y en la interior.

119. Pérez SARRIón (2012: 37 y 393); GRAFE (2012: 97); LlOPIS y SOTOCA (2005: 249-251).

120. PÉREZ SARRIÓN (2012: 382 y 450-45)1; RINGROSE (1996: 60-61 y 76-86).

121. GRAFE (2012: 114-115, 213 y 240).

122. GARCía SANZ (1996: 187-192); PÉREZ SARRIón (2012: 231-321). 
En Galicia y la cornisa cantábrica, la recuperación fue relativamente temprana y las transformaciones económicas, en torno a la revolución del maíz, alcanzaron gran magnitud en los valles litorales y prelitorales ${ }^{123}$. A la Galicia interior también acabaron llegando importantes novedades desde 1750: la difusión del maíz y del nabo y la introducción de la patata, las rotaciones de cosechas, el retroceso del barbecho y la estabulación de una mayor proporción del ganado de labor ${ }^{124}$. Cuando la revolución del maíz entró en fase de rendimientos decrecientes, en diversas fechas del Setecientos en las distintas comarcas gallegas, asturianas, cántabras y vascas, otros factores ganaron protagonismo en el sostenimiento o aceleración de su crecimiento demográfico y económico: el avance más rápido de las roturaciones, la intensificación de los movimientos migratorios estacionales y temporales, el desarrollo de la industria rural (en Galicia), el crecimiento del comercio interior y exterior y la expansión del transporte ${ }^{125}$. En suma, en la España húmeda, los cultivos americanos, el uso cada vez más intensivo del factor trabajo en los hogares rurales, las roturaciones y el impulso de los sectores no agrarios, en buena medida vinculado al desarrollo de la economía atlántica, sostuvieron un notable aumento de la población y uno más modesto del PIB per cápita en la segunda mitad del siglo XVII y en el XVIII. La España cantábrica constituye un buen paradigma de aquellas áreas europeas en las que casi todo el crecimiento preindustrial se consumió en sustentar una población crecientemente densa ${ }^{126}$. Ahora bien, la moderación de la mortalidad en Cantabria o en Galicia apunta a que también se registró una mejora de los niveles de vida en esas regiones en el Setecientos ${ }^{127}$.

El arranque del crecimiento económico premoderno en Cataluña también data de fechas relativamente precoces, el último cuarto del siglo XVII, cuando las guerras franco-holandesas y la inserción del comercio catalán en los circuitos atlánticos posibilitaron un notable desarrollo de la producción de vino y aguardiente en el Principado. Este disponía de tierras (zonas boscosas que podían plantarse de vides), instituciones (ante todo, la rabassa morta) y capital humano idóneos para la expansión de dicha actividad ${ }^{128}$. Y el desarrollo de la viticultura tuvo un papel decisivo en la intensificación de los cultivos, la elevación de la renta por habitante, la especialización comarcal y el crecimiento del mercado regional en el Setecientos. Varios factores sostuvieron e impulsaron el crecimiento de la

123. SaAvedra (1985: 229-230); ANes (1988: 34-38); LANZA (2010: 87-93); BilbaO y FernándeZ DE PINEDO (1984: 113-124).

124. SAAVEDRA (1985: 260-277).

125. FERnÁNDEZ de Pinedo (1974: 197-204); LANZA (2010: 105-108 y 151-248); SAAVEdRa (1985: 184 y 278-279); CARMONA y NADAL (2005: 4-58).

126. Clark (2007: 1) sostiene que antes de 1800 el crecimiento de la población eliminaba los pequeños incrementos registrados previamente en la renta por habitante.

127. AbarCa y LANZa (2013); SAAVEDRA (1985: 109-115).

128. VAlls (2004: 49-63); TORRAS (1994: 17-22). 
economía catalana y la transformación de las industrias de la lana, del estampado de lienzos y del algodón durante el siglo XVIII: el dinamismo de la economía atlántica; la supresión de las aduanas interiores tras la Guerra de Sucesión ${ }^{129}$; las potentes redes mercantiles de catalanes desplegadas por gran parte de la penínsu$\mathrm{la}^{130}$; el libre comercio con las colonias americanas ${ }^{131}$, y la fiscalidad, cada vez más benigna al basarse en un impuesto de cupo (el catastro) cuyo monto apenas fue actualizado, en absoluto al intenso ritmo de aumento de la población y del PIB regional ${ }^{132}$. En suma, el más fácil acceso a los mercados español, colonial y europeo, por avatares históricos y cambios legislativos, fue relevante para la prosperidad de la economía catalana en el Setecientos, pero esta última en absoluto resultó ajena a fenómenos endógenos, propios de región: la existencia de suelos e instituciones adecuados para la expansión de la viticultura y de un capital humano acumulado capaz de sacar provecho a las oportunidades mercantiles y de promover la transformación de importantes ramas de la manufactura. Varios de estos factores estaban presentes asimismo en el País Valenciano, donde la extensión y, sobre todo, la intensificación de los cultivos, también se iniciaron en el último cuarto del Seiscientos. Desde entonces, en palabras de Ardit, «el procés de creixement agrari, temporalment interromput per les greus conseqüències de la Guerra de Successió i periòdicament sacsejat per les oscillacions cícliques sempre presents a les economies de l'Antic Règim, ja no fou interromput fins als nostres dies» ${ }^{133}$. Más allá del notable avance de la viticultura ${ }^{134}$, se operó un relevante desarrollo de la agricultura de regadío, ampliándose el cultivo de la morera y del arroz ${ }^{135}$. La difusión de la sericicultura en el mundo rural, amén de propiciar la intensificación del trabajo de las familias campesinas, sustentó una fuerte expansión de la industria sedera, que se sumó a la registrada en ciertas zonas por la pañería ${ }^{136}$. Todo ello alimentó un intenso aumento de la actividad comercial, con un papel señero de las urbes de Valencia y Alicante ${ }^{137}$. Y, como señala Ardit, «entre 1680 i 1780, per fixar dues dades còmodes, tingué lloc bàsicament el procés de transformació» ${ }^{138}$.

129. La supresión de las aduanas interiores entrañó que «los paños catalanes colocados en Castilla dejaran de pagar entre un 11,3 y un 26,3\% en impuestos según valor en arancel», PÉREZ SARRIÓN (2012: 267).

130. PÉREZ SARRIÓN (2012: 394-451).

131. "Los años de 1783 a 1796, de plenitud de los intercambios con América, fueron también la época dorada de la indianería catalana», Helguera y SÁnCHEZ SuÁrez (2003: 51).

132. Pérez SARrión (2012: 398-399); RuIZ TORRes (2008: 258-259).

133. ARDIT (1993: 265)

134. PIQUERAS (1981).

135. Bernabé (2010); Alberola (2015); Franch (2000); Mateu (1987).

136. FRANCH (1994 y 2000); TORRó (2000). La distribución sectorial de la población activa según los datos del Censo de 1797 indica que la región valenciana era, tras Cataluña, la de mayor proporción de población activa industrial; LLOPIS (2001: 511).

137. FRANCH (1986); GimÉNEZ (1981).

138. ARDIT (1993: 265-266). 
Los datos demográficos del interior peninsular apuntan claramente a una mejora de sus resultados económicos entre la primera y la segunda mitad del siglo XVIII: el crecimiento de la población se aceleró, la mortalidad se moderó y las crisis, tanto las de natalidad como las de mortalidad, retrocedieron de manera significativa. Y tales cambios positivos acaecieron, precisamente, cuando esta extensa región, a mediados del siglo, acababa de recuperar los máximos demográficos de finales del Quinientos y, por consiguiente, las fuerzas malthusianas tendrían que haber comenzado a actuar ${ }^{139}$.

¿Qué factores determinaron la mejora aludida en la situación económica de la población rural del interior del país? No disponemos de suficiente información para responder de modo plenamente fundamentado a este interrogante, pero sí contamos con diversas evidencias y pistas al respecto. Estas sugieren que, sobre unas economías familiares que estaban registrando importantes cambios endógenos, vinieron a incidir varios fenómenos de carácter exógeno: el desarrollo de las actividades mercantiles, impulsado por la urbanización del país; la parcial liberalización del comercio interior y exterior de granos; el aumento de la demanda de cereales de la periferia marítima; las pequeñas mejoras en las infraestructuras viarias; el libre comercio con las colonias americanas, y el notable aumento de los tráficos con el resto de Europa ${ }^{140}$. Por sí solo, cada uno de estos factores tenía una capacidad relativamente limitada de transformar la economía rural de la España interior, pero la suma de todos y su interacción sí ejerció un impacto apreciable sobre muchas economías campesinas, sobre todo porque en su seno algo estaba cambiando: un conjunto de presiones y oportunidades estaba propiciando que, vía intensificación del uso de la mano de obra disponible, elevasen sus niveles de actividad económica, y la expansión de los mercados aportó un estímulo añadido.

En el apartado de las presiones, buena parte de los cultivadores del interior del país, hacia 1750, afrontaba problemas de envergadura: el tamaño de sus explotaciones apenas era suficiente, o no lo era en absoluto, para lograr los ingresos que aseguraban la subsistencia y la reproducción de sus familias ${ }^{141}$; aunque existiese margen para extender los cultivos ${ }^{142}$, los grandes propietarios territoriales, las oligarquías locales con intereses ganaderos y la Mesta dificultaban enormemente

139. Desde la perspectiva del estatus nutricional o nivel de vida biológico, resulta significativa la ausencia de una fuerte caída en la talla media de los nacidos en las décadas de 1760, 1770 y 1780 que se infiere del estudio de los padrones de alistamiento de los mismos, entre 1768 y 1787 , en 99 localidades de la antigua provincia de Toledo. García Montero (2010: 36-37).

140. Álvarez-Nogal y Prados (2013: 14); Llopis (2004b: 73-85); Madrazo (1984: vol. 1, 151376); Palop (1977: 29-72); Tinoco y Fradera (1987: 317-324); Delgado (1987); Marcos (2000: 678-695).

141. Basta ojear los Libros de Hacienda de seglares de las Respuestas Particulares del Catastro de cierto número de localidades de distintas provincias castellanas para apreciar el fenómeno.

142. Este seguía siendo bastante amplio en muchos territorios de la España interior, sobre todo en sus áreas meridionales; de hecho, después, en las seis primeras décadas del siglo XIX, la superficie cultivada se incrementaría en el conjunto del país cerca de un 50\%. Llopis (2004a: 30-32). 
los rompimientos ${ }^{143}$; la renta de la tierra suponía a menudo una pesada carga para ellos, y venía aumentando desde el último tramo del siglo XVII ${ }^{144}$; y, por último, el diezmo era un tributo muy oneroso que absorbía un alto porcentaje de sus ingresos netos ${ }^{145}$.

En el capítulo de las oportunidades, desde el ecuador de la centuria se advierten cambios políticos y sociales que acabaron ampliando el margen de actuación de los productores directos: de una parte, las acciones del absolutismo borbónico, decidido a consolidarse, abrieron fisuras en el bloque social en el poder, en especial respecto a la posición de la Iglesia en el mismo; de otra, se aprecia un fortalecimiento político de los grupos no privilegiados, que el absolutismo ilustrado no podía desatender.

Las novedades fiscales introducidas en 1749 , de enjundia ${ }^{146}$, pusieron nerviosos tanto al clero, como a la nobleza y a las oligarquías municipales, que desplegaron una tenaz resistencia. Los nobles, una vez que la efectiva aplicación de la única contribución se dejó definitivamente de lado, en 1776, solo tuvieron que transigir con algún recorte en el terreno de la jurisdicción señorial, si bien los más implicados en el ejercicio del poder municipal y/o más vinculados al negocio ganadero tuvieron que afrontar los perjuicios que les causasen los repartos de tierras concejiles y la creciente erosión de los privilegios mesteños ${ }^{147}$. En todo caso, parece que las oligarquías que controlaban los gobiernos locales y tan opuestas se habían mostrado a facilitar los rompimientos de tierras incultas en la primera mitad del Setecientos relajaron su resistencia en sus últimas décadas, sobre todo luego de lo sucedido en Francia en $1789^{148}$. Para la Iglesia las cosas fueron más serias, en la medida en que el fortalecimiento del poder regio pasaba por su subordinación al trono ${ }^{149}$. Desde la firma del concordato de 1753 hasta la desamortización de 1798, el poder y la influencia de la Iglesia como institución y del alto clero como conspicuo miembro del bloque social en el poder sufrieron un proceso de erosión notable ${ }^{150}$. A la percepción de este por parte de la población rural se añadió la pérdida de prestigio y de ascendiente sobre la misma que supuso el aumento de los conflictos entre los propios eclesiásticos por motivos estrictamente temporales como el reparto del producto decimal. El fortalecimiento político de los

143. LLOPIS (2002: 127-129).

144. García Sanz (1977: 300-310); Álvarez VÁzQuez (1987: 76-92); Sebastián (1990: 59); Cuervo (2006).

145. ANES (1970: 293-295).

146. El proyecto de sustitución, en las 22 provincias de la Corona de Castilla, de las rentas provinciales por la única contribución, que no contemplaba exenciones para los privilegiados, y el inicio de las pesquisas sobre la riqueza y posesiones de los castellanos que constituirían el Catastro de Ensenada.

147. Herr (1979: 94); GARCÍA SANZ (1996: 175).

148. LlOPIS y SÁNCHEZ SALAZAR (2016: 299).

149. HERR (1979: 9-12).

150. Herr (1979: 9-30, y 1991: 111-184); FERNÁNDEZ DÍAZ (2016: 239). 
no privilegiados fue la otra cara de estas transformaciones, como mostraron los motines y revueltas de 1766, de una extensión y virulencia inusitadas y con una confluencia tan variada de motivos y sectores sociales que obligó a la Monarquía a no perder de vista, desde entonces, a la incipiente opinión pública ${ }^{151}$.

En este contexto, los cultivadores hallaron suficientes resquicios para acometer roturaciones, tanto legales como ilegales, de tierras ${ }^{152}$ y para aumentar su resistencia al pago del diezmo, así como nuevos motivos para incrementar su esfuerzo laboral y el de sus familias. La ampliación de los rompimientos no entrañó un descenso de la renta de la tierra, pero sí parece que contribuyó a moderar su ritmo de ascenso ${ }^{153}$. En cuanto a la exacción del diezmo, las acciones de los productores sugieren un salto cualitativo, de las resistencias tradicionales a la creciente defraudación, en las cuatro últimas décadas del siglo XVIII. No se llegaría aún a negar el pago del tributo, lo que menudearía después, al hilo de la profunda crisis de 1803-1805 ${ }^{154}$, pero sí a cuestionar la legitimidad de que el diezmo gravase el producto bruto y obviase los costes que suponía obtener lo cosechado. Los cultivadores optaron por salvar las apariencias y vulnerar el fondo del asunto: se avisaba a colectores y terceros para que asistiesen al cubicaje de las mieses en las eras, pero tratando de evitar su presencia efectiva, a fin de descontar la simiente y otros gastos de las cosechas de cereales ${ }^{155}$; se procuraba extender el cultivo de frutos que pagaban tarifas inferiores al 10\% o que estaban exentos de diezmar; y si los párrocos se avenían a consentir un pago menos riguroso del tributo, a cambio de engrosar sus diezmos privativos, las acciones de los labriegos hallaban cobertura para ampliarse y ocultarse a la inspección de las instituciones a las que pertenecía el grueso de los derechos decimales. Todo ello hubo de implicar que la tasa efectiva satisfecha por los cultivadores en concepto de diezmo se redujese dos o más puntos en términos brutos y una proporción mucho más significativa en términos netos. Probablemente, ninguna otra estrategia ligada al aumento de la laboriosidad de los hogares rurales en la segunda mitad del siglo

151. El motín contra Esquilache incluyó graves desórdenes en Madrid, primero, y en un total de treinta y seis ciudades, después; se saldó en la capital con 40 muertos y, en esta y otros muchos núcleos, fue en sus motivaciones más allá de un clásico motín de subsistencias. Fernández Díaz (2016: 236-244); LÓPEZ GARCÍA (2006).

152. Sobre la intensificación de las roturaciones en la segunda mitad del siglo XVIII, SÁNCHEZ SALAZAR (1988: 66); LLOPIS y SÁNCHEZ SALAZAR (2016: 297-298).

153. En Zamora, la renta de la tierra se estancó en la segunda mitad del siglo (Llopis, 2002: 132). En el Oriente leonés, la renta percibida en especie por 17 fincas del monasterio de Sandoval creció con mucha más intensidad entre 1690-1692 y 1750-1754 (un 47,3\%, a una tasa anual del 0,65\%) que entre 1750-1754 y 1790-1799 (un 14,9\%, a una tasa anual del 0,35\%); SEBASTIÁN (1992: 1126-1129 y 1138-1141).

154. LLOPIS y SÁNCHEZ SALAZAR (2016: 296).

155. Probablemente, este es el significado de lo que, hacia 1775 , declaraban numerosos cosecheros del obispado de Burgos: al no estar presentes los colectores en las eras cuando se levantaban los montones de granos, pagaban el diezmo «según conciencia» (ABARCA, 2015: 303). 
XVIII, en la España interior, deparó más alivio a las economías campesinas que la defraudación en el pago del diezmo.

Simultáneamente, el crecimiento de la demanda, derivado de la urbanización, del aumento de la población, de los intercambios con la periferia y de las exportaciones, estimuló la producción agraria e hizo posible que, en numerosas familias rurales del interior, uno o varios miembros participasen algo más activamente en la producción de manufacturas, el carboneo, el transporte y la provisión de pequeños servicios. Consideramos relevante remarcar que muchos habitantes del interior peninsular, aun a costa de hacer un uso más intensivo de su mano de obra y de restarle tiempo al ocio, pudieron desarrollar un conjunto de pequeñas actividades productivas, merced en parte al desarrollo de los mercados, que tornaron algo más sólidas sus economías familiares.

En definitiva, no pretendemos pintar de color rosa la economía española de la segunda mitad del Setecientos, pero sí consideramos que existen motivos suficientes como para aplicarle tonos menos oscuros. La caída de la mortalidad en varias regiones difícilmente podría haber acaecido sin que la mayoría de las familias que las poblaban hubiese registrado un aumento, por modesto que fuese, de la cuantía y la estabilidad de sus ingresos. Los contrapuntos que se observan en la última década del siglo son muy significativos: ¿cómo explicar que, en su transcurso, se produjese un intenso crecimiento de los precios de las subsistencias, sobre todo de los granos, y una brusca caída de los salarios reales, a la par que la mortalidad seguía reduciéndose y, en especial, que el número de bautizados registraba un postrero, y relevante, impulso al alza? Si el grueso del aumento de los precios en la década de 1790 se debiese más a tensiones en los mercados generadas por el intenso crecimiento de la demanda ${ }^{156}$ que a notables mermas de los niveles productivos, los cuales, estimados a partir de fuentes decimales, estarían incluyendo una notable infravaloración, ocultando una fracción del producto agrario integrada en gran parte por frutos, como leguminosas y patatas, de mayor impacto en la dieta de las familias rurales que en la porción comercializada de sus cosechas, cabría entender que estas estuviesen levantando un tanto el freno de sus comportamientos reproductores, y tendríamos quizá una acertada explicación ${ }^{157}$. No obstante, en aquellas zonas donde prevalecían las familias jornaleras, cuyos ingresos dependían en un alto porcentaje de rentas salariales, el deterioro de su situación hubo de ser innegable. En este sentido, existe un motivo importante para no exagerar el optimismo: el balance económico menos satisfactorio en términos comparativos, en la segunda mitad del siglo XVIII, de las regiones del sur peninsular. Y, como es sabido, Andalucía tenía un notable peso en la población y en la economía de la España de finales del Antiguo Régimen. ¿Es posible que una

156. LLOPIS (2013: 98-105); LLOPIS y SÁNCHEZ SALAZAR (2016: 296-300).

157. Añádase que todo indica que el decenio de 1790 fue un período de fuerte impulso roturador. Llopis y SÁNCHEZ SALAZAR (2016: 298). 
excesiva desigualdad económica hubiese frenado el cambio económico, político y social en las regiones meridionales? ${ }^{\text {?58 }}$. De momento, esto constituye una mera hipótesis sin testar.

En todo caso, a nivel general, la fase expansiva del Setecientos, sobre todo de su segunda mitad, se prolongó hasta finalizar la centuria. Hacia 1800, sin embargo, la economía española había acumulado suficientes problemas y amenazas de índole tan variada (sobre ciertas producciones manufactureras, el comercio exterior, el colonial y el interior, las finanzas públicas, las instituciones políticas y sociales, las relaciones con otros países, la defensa de las colonias americanas) como para que presagios bastante sombríos dominasen su futuro inmediato.

\section{CONCLUSIONES Y CONSIDERACIONES FINALES}

El examen crítico de un amplio conjunto de registros sacramentales y decimales, de las series vitales y estimaciones de niveles productivos que consienten construir, de numerosos materiales publicados y de una amplia bibliografía permite sostener una visión de la economía española en el siglo XVIII, en especial en su segunda mitad, más positiva que la ofrecida tradicionalmente. Sus fundamentos son los siguientes:

1) La notable intensidad con que la población española creció en el Setecientos, homologable con la del resto de Europa occidental, y la aceleración de ese incremento demográfico en la mayoría de sus regiones en la segunda mitad de la centuria. Ese cambio de velocidad, precisamente cuando la densidad demográfica era mayor, indica que el modelo malthusiano no puede proporcionar la clave interpretativa esencial del desempeño de la economía española entre 1750 y 1800.

2) La simultaneidad con que ese relevante crecimiento poblacional (y, a la fuerza, económico) se operó en la mayor parte de los espacios peninsulares, crecimiento que, desde mediados de la centuria, se estaría produciendo en términos netos, luego de que las vastas regiones del interior recobrasen los niveles demográficos y económicos perdidos a finales del siglo XVI. Las Españas levantina, septentrional e interior acudieron a la cita superando desajustes anteriores; Andalucía también se sumó a ese encuentro, pero con un vigor claramente inferior.

3) El protagonismo del descenso de la mortalidad en el aumento de la población en la segunda mitad del Setecientos, en especial de la mortalidad ordinaria y sobre todo de la adulta. No resulta verosímil que ello hubiese

158. Somos conscientes, en todo caso, de la notable diversidad interna de la economía agraria andaluza, que no cabe reducir al binomio latifundio/jornaleros. GonZÁLEz DE Molina y SEvilla (1991: 114-121). 
acaecido en buena parte del país sin mejora económica alguna, en especial sin algún cambio positivo en la dieta de la mayoría de sus habitantes.

4) La mortalidad catastrófica también retrocedió después de 1750, y las crisis de natalidad y mortalidad fueron menos frecuentes e intensas en la segunda mitad del siglo en numerosos territorios peninsulares.

5) La producción agraria aumentó y se diversificó en la España del siglo XVIII ${ }^{159}$, aunque los diezmos, las mejores fuentes para calcular su trayectoria, infravaloran su crecimiento, sobre todo desde 1760. En las cuatro últimas décadas de la centuria, los vaivenes en la gestión del Excusado, los conflictos de intereses entre los distintos miembros e instancias del clero y la creciente defraudación practicada por los cultivadores ampliaron la porción del producto agrario que no dejaba huella en la masa decimal, ocultando en parte sus niveles y los cambios en su composición.

6) El producto no agrario se incrementó más que el del sector primario en la España del siglo XVIII, sobre todo en su segunda mitad. Así lo indican la evolución de la tasa de urbanización; el dinamismo de ciertas manufacturas, como las catalanas de estampado de lienzos, lana y algodón; los avances de agroindustrias vinculadas a la exportación, como las que producían vinos y aguardientes; el intenso aumento de los tráficos comerciales con el exterior; el progreso del comercio interior y el desarrollo de redes mercantiles que activaron y empezaron a articular el mercado interno, y la expansión de las actividades no agrarias en el mundo rural. España o, al menos, áreas sustanciales de su territorio, tuvieron su pequeña revolución industriosa en la segunda mitad del Setecientos, si bien la intensificación del uso de la mano de obra disponible (femenina, quizá de modo especial) buscó, ante todo, contrarrestar tendencias muy preocupantes para las familias campesinas, como el descenso de los salarios reales, el alza de la renta de la tierra y la reducción del tamaño medio de sus explotaciones.

7) En suma, si el producto agrario por persona, como parece verosímil, aumentó en España durante el siglo XVIII a una tasa anual no inferior al $0,1 \%$, y habida cuenta del mayor ritmo de incremento del producto no

159. Fenómeno que no sería exclusivo de la porción española de la península Ibérica. SERRÃo (2007 y 2017) ha enfatizado el dinámico comportamiento del sector agrario portugués en el Setecientos. La agricultura portuguesa registró en su transcurso una creciente diversificación productiva y diferentes progresos en variados aspectos; aunque no conoció una revolución agrícola que elevase la producción de modo espectacular y alterase radicalmente los paisajes agrarios, las técnicas aplicadas y las formas o los titulares de la propiedad de la tierra, Serrão apunta que no deben subestimarse la continuación y consolidación de la revolución del maíz y de la revolución del viñedo, el avance del cultivo de leguminosas, el inicio de una revolución de la patata, la creciente dependencia del mercado, el incremento de las exportaciones agropecuarias y, quizá por encima de todo, la continuidad del crecimiento demográfico. SERRÃO (2007: 61). 
agrario, el PIB por habitante habría crecido, cuando menos, a una tasa cercana al $0,15 \%$.

¿Habían situado todas estas transformaciones a nuestro país, hacia 1800, en una posición sólida, halagüeña incluso, de cara al futuro? Por persuadidos que estemos de que España logró en la segunda mitad del siglo XVIII un balance económico más positivo que el que usualmente se ha presentado, nuestra respuesta debe ser negativa: aquellas no resultaron suficientes ante la índole de los problemas acumulados y la magnitud de las amenazas que, con el cambio de siglo, se cernían sobre la economía peninsular.

1) En su conjunto, el crecimiento económico del Setecientos fue insuficiente para dar acomodo adecuado a los grupos sociales más desposeídos y vino acompañado de un incremento de la desigualdad. A finales de la centuria, en un contexto de notable inflación e intensa caída de los salarios reales ${ }^{160}$, la población urbana que vivía en la marginalidad o en sus aledaños estaba creciendo y, pese al mayor esfuerzo laboral de sus miembros, también estaba aumentando la vulnerabilidad de las familias rurales cuyos ingresos estaban mayoritariamente integrados por jornales y/o el producto de minúsculas explotaciones agrarias.

2) Los riesgos de fractura social no provenían, en exclusiva, de los sectores más desfavorecidos. En las áreas rurales, cultivadores que no cabe incluir en estos, desde renteros y enfiteutas cuyas explotaciones proveían, un año con otro, el grueso de su subsistencia hasta labradores y arrendatarios acomodados, algunos ya insertos en las oligarquías locales, estaban poniendo en cuestión el tradicional reparto del producto agrario. Su destacada participación en la defraudación en el pago del diezmo, en las roturaciones y repartos de tierras municipales y en la desamortización de 1798 revelan su afán por ampliar su parte en un crecimiento agrario innegable, pero en absoluto revolucionario en la mayor parte del país. En las ciudades, la intranquilidad también se estaba instalando entre el alto clero, por motivos obvios, y entre sectores burgueses, ya se dedicasen a negocios tan tradicionales como el arrendamiento de la percepción de diezmos y derechos señoriales, cuyo pago era crecientemente contestado, en la más mortecina de las urbes del interior, ya se hubiesen orientado, en las áreas litorales más dinámicas, hacia actividades manufactureras y comerciales, duramente afectadas por la desfavorable evolución de los términos de intercambio de sus producciones ante el intenso

160. Conviene citar el ejemplo que ofrecen JOVER y MANERA (2017: 21-26), por tratarse de salarios agrícolas. 
aumento de los precios de los granos y por las irregularidades y colapsos de los tráficos coloniales y exteriores, sobre todo desde 1796.

3) El impacto de los sucesos revolucionarios franceses, el casi permanente estado de guerra desde 1793 (en el mar y en los puertos, pero también en tierra, dentro de las fronteras del país), las crecientes dificultades para financiar el esfuerzo bélico y los diversos expedientes puestos en marcha para afrontar los apuros de la Hacienda, con un notable aumento de la carga fiscal en primer término ${ }^{161}$, estaban generando una creciente inestabilidad política e institucional.

4) El papel de las colonias americanas en el conjunto de la Monarquía creció de modo considerable durante el Setecientos, pero las relaciones y vínculos entre imperio y metrópoli fueron acumulando contradicciones cada vez más difíciles de resolver. De un lado, las Indias adquirieron, sobre todo desde mediados del siglo, una importancia creciente para la economía española, primordial para los tráficos comerciales y el progreso de las zonas litorales más prósperas e indispensable para los ingresos de la Hacienda ${ }^{162}$; de otro, su defensa se tornó cada vez más difícil y costosa. La hegemonía naval de Inglaterra y la imposibilidad de alcanzar, en toda la centuria, un acuerdo mínimamente favorable y duradero con este país, el principal competidor en el aprovechamiento económico y comercial de los territorios americanos, dificultaron y encarecieron la citada empresa. Además, el propio crecimiento económico de algunos espacios coloniales en el siglo XVIII, como Nueva España, favorable en principio a los intereses de la metrópoli, fortaleció a las elites criollas, que comenzaron a mirar a esta con un apego decreciente. A finales del siglo, la acuciante necesidad de incrementar las remesas de las Indias empujó a los gobiernos borbónicos a elevar fuertemente la presión fiscal sobre las mismas, lo que impulsó la difusión y el arraigo de opiniones favorables a la emancipación.

5) Por último, hacia 1800, aunque obstaculizada por guerras navales y bloqueos, la amenaza de la revolución industrial que se había iniciado en otras zonas de Europa varios años antes también estaba presente. La llegada legal, e ilegal vía contrabando, de los productos de la misma, textiles especialmente, sería un obstáculo formidable en un futuro cercano para las actividades manufactureras de muchas familias rurales, contribuyendo a cegar una de las estrategias de sobrevivencia que habían fructificado en el siglo XVIII, y para los procesos de producción textil que,

161. El esfuerzo fiscal por habitante, empujado básicamente por los gastos de guerra, aumentó en España un 30\% entre 1775 y 1796. Comín (2016: 108-109).

162. La contribución fiscal americana a los ingresos ordinarios de la Monarquía, cercana al $15 \%$ en 1763-1783, superó por poco el 25\% en la década de 1790. MARICHAL (1997: 478 y 484). 
sobre todo en Cataluña, habían iniciado el tránsito hacia la nueva industria. A la postre, la amenaza que los géneros catalanes implicaba para los de dicha industria rural resultaría mucho mayor que la supuesta por los ingleses: bien entrado el siglo XIX, combatido el contrabando e instalado el prohibicionismo como eje de la política comercial, los unos darían la puntilla a los otros ${ }^{163}$. En el ínterin, la intensa crisis de 18031805, la pérdida efectiva del imperio americano, la invasión francesa y el impacto y las secuelas de una guerra tan larga como cruel llevarían al extremo muchos de los desequilibrios y fracturas que se advertían hacia 1800 .

\section{BiBLIOGRAFÍA}

Abarca Abarca, Vanesa. Campos conocidos, senderos nuevos. Población y producción agraria en Burgos, 1540-1865. Madrid: Universidad Complutense de Madrid, 2015, tesis doctoral inédita.

ABARCA ABARCA, Vanesa. "Mortalidad y crecimiento vegetativo en la provincia de Burgos, 1650-1865". Investigaciones de Historia Económica, 2017, 13, 3, pp. 153-165.

ABARCA, Vanesa y LANZA, Ramón. "El declive de la mortalidad en el interior castellano y la costa cantábrica, 1700-1860: un estudio comparado». Comunicación presentada al XIV Congreso de la Sociedad Española de Historia Agraria. Badajoz, 2013.

Abarca, Vanesa; Llopis, Enrique; SÁnchez SalazAr, Felipa y Velasco, Eduardo. "El declive de la mortalidad en la provincia de Zamora en los siglos XVIII y XIX". Revista Uruguaya de Historia Económica, 2016, vol. VI, 9, pp. 9-30.

Abarca, Vanesa; Llopis, Enrique; Sebastián, José Antonio; Bernardos, José Ubaldo y VeLASCO, Ángel Luis. «El descenso de la mortalidad en territorios de la España interior de elevada desigualdad económica: Albacete y Ciudad Real, 1700-1895”. América Latina en la Historia Económica, 2015, año 22, 3, pp. 108-144.

ALBEROLA ROMÁ, Armando. "No puedo sujetar la pluma de puro frío, porque son extremados los yelos: el clima en la España de los reinados de Felipe V y Fernando VI a través de la correspondencia de algunos ilustrados». Investigaciones Geográficas, 2009, 49, pp. 65-88.

AlBerola Romá, Armando. "Propiedad, control y gestión del agua en regadíos deficitarios del Sureste español: la huerta de Alicante durante la Edad Moderna». Minius, 2015, 23, pp. 7-40.

ALLEN, Robert C. «Economic structure and agricultural productivity in Europe, 1300-1800». European Review of Economic History, 2000, 3, 2, pp. 1-25.

Álvarez VÁzQuez, José Antonio. Rentas, precios y crédito en Zamora en el Antiguo Régimen. Zamora: Colegio Universitario de Zamora, 1987.

Álvarez-Nogal, Carlos y Prados De la Escosura, Leandro. "The Decline of Spain (15001850): Conjectural Estimates». European Review of Economic History, 2007, 11, pp. 319-366.

163. Benaul (1991: 784); HeRnández García (2010: 100). 
Álvarez-Nogal, Carlos y Prados de la Escosura, Leandro. «The rise and fall of Spain (12701850)». Economic History Review, 2013, 66, pp. 1-37.

Álvarez-Nogal, Carlos; Prados, Leandro y Santiago-Caballero, Carlos. «Spanish Agriculture in the Little Divergence». European Review of Economic History, 2016, 20, 4, pp. 452-477.

ANES ÁlVAREz, Gonzalo. Las crisis agrarias en la España moderna. Madrid: Taurus, 1970.

ANes Álvarez, Gonzalo. Economía y sociedad en la Asturias del Antiguo Régimen. Barcelona: Ariel, 1988.

ARDIT LUCAS, Manuel. "Recaudación y fraude diezmal en el siglo XVIII valenciano». En VV. AA. Estructuras agrarias y reformismo ilustrado en la España del siglo XVIII. Madrid: Ministerio de Agricultura, 1989, pp. 391-410.

ARDIT LuCAS, Manuel. Els homes i la terra del País Valenciá (segles XVI-XVIII). Barcelona: Curial, 1993.

ARdit LuCAS, Manuel. El Siglo de las Luces. Economía. Madrid: Síntesis, 2007.

Barrio Gozalo, Maximiliano. El Real patronato y los obispos españoles del Antiguo Régimen (1556-1834). Madrid: Centro de Estudios Políticos y Constitucionales, 2004.

Benaul Berenguer, Josep María. La industria textil llanera a Catalunya, 1750-1870. El procés d'industrialització al districte industrial de Sabadell-Terrassa. Barcelona: Universidad Autónoma de Barcelona, 1991, tesis doctoral inédita.

Benaul Berenguer, Josep María. "Los orígenes de la industria textil lanera en Sabadell y Terrasa en el siglo XVIII. Revista de Historia Industrial, 1992, 1, pp. 39-62.

Bernabé GIL, David. "Regadío y transformación de los espacios jurisdiccionales en el Bajo Segura durante la época foral moderna». Investigaciones Geográficas, 2010, 53, pp. 73-84.

BERnal, Antonio-Miguel y Macías, Antonio Manuel. "Canarias, 1400-1936: el modelo de crecimiento en perspectiva histórica». En VV. AA. Economía e insularidad (siglos XIV-XX). La Laguna: Universidad de La Laguna, 2007, vol. 1, pp. 11-52.

BERNARDOS SANZ, José Ubaldo. Trigo castellano y abasto madrileño: los arrieros y comerciantes segovianos en la Edad Moderna. Valladolid: Junta de Castilla y León, 2003.

BERNAT MARTí, Joan Serafí. "La disminución a largo plazo de la mortalidad en el País Valenciano, 1700-1864». Comunicación presentada al XIV Congreso de la Sociedad Española de Historia Agraria. Badajoz, 2013.

BERnat, Joan Serafí y BADENES, Miguel Ángel. "Cronología, intensidad y extensión de las crisis demográficas en el País Valencià (siglos XVII-XIX)». En PéreZ Aparicio, C. (ed.). Estudis sobre la població del País Valencià, vol. I. Valencia: Ediciones Alfonso el Magnánimo e Instituto de Estudios Juan Gil-Albert, 1988, pp. 537-557.

BilbaO, Luis María y Fernández De PINEDO, Emiliano. "La producción agrícola en el País Vasco peninsular, 1537-1850: tendencia general y contrastes comarcales, una aproximación». Vasconia: Cuadernos de Historia-Geografía, 1984, 2, pp. 83-198.

Broadberry, Stephen; CAmpbell, Bruce; Klein, Alexander; Overton, Mark y Leeuwen, Bas van. "British Economic Growth, 1270-1870: an output-based approach". University of Kent School of Economics Discussion Papers, KDPE 1203, 2011, ftp://ftp.ukc.ac.uk/ pub/ejr/RePEc/ukc/ukcedp /1203.pdf.

Broadberry, Stephen; CampBell, Bruce; Klein, Alexander; Overton, Mark y Leeuwen, Bas van. British Economic Growth, 1270-1870. Cambridge: Cambridge University Press, 2015. 
BuYsT, Erik. "Towards estimates of long term growth in the southern Low Countries, $c$. 1500-1846». Unpublished paper presented at The Quantifying Long Run Economic Development Conference. University of Warwick in Venice, 22-24 March, 2011.

CANALES, Esteban. «Los diezmos en su etapa final». En ANES, G. (ed.). La economía española al final del Antiguo Régimen. I. Agricultura. Madrid: Alianza, 1982, pp. 105-187.

Carmona Badía, Xán. El atraso industrial de Galicia. Auge y liquidación de las manufacturas textiles, 1750-1900. Barcelona: Ariel, 1990.

Carmona, Xán y NADAL, Jordi. El empeño industrial de Galicia. 250 años de historia, 17502000. La Coruña: Fundación Pedro Barrié de la Maza, 2005.

CATALÁn MARTínEZ, Elena. «Evolución del producto agrario bruto y especialización regional. La Rioja, 1545-1800». Comunicación presentada al IX Congreso de la AEHE. Murcia, 2008.

CATALÁN MARTíneZ, Elena. "El crecimiento del producto agrario por habitante en La Rioja en la Edad Moderna». Investigaciones de Historia Económica, 2018, 14, 2, pp. 82-93.

CATALÁN, Elena y LANZA, Ramón. "Alimentación, carestías y crisis de mortalidad en la España cantábrica (1680-1860)». Historia Agraria, 2015, 67, pp. 11-42.

CHESNAIS, Jean-Claude. La transition démographique. Etapes, formes, implications économiques. Étude de séries temporelles (1720-1984) relatives à 67 pays. París: INED, Presses Universitaires de France, 1986.

Clark, Gregory. A Farewell to Alms. A Brief Economic History of the World. Princeton and Oxford: Princeton University Press, 2007.

CLARK, Gregory. «The macroeconomic aggregates for England, 1209-2008». En FIELD A. J. (ed.). Research in Economic History, 2010, 27, Emerald Group Publishing Limited, pp. 51-140.

Comín Comín, Francisco. Las crisis de la deuda soberana en España (1500-2015). Madrid: Los Libros de la Catarata, 2016.

Cuervo FuENTE, Noemí. «La renta de la tierra y su evolución en la mitad norte de la provincia de Ávila en los siglos XVI y XVII». Investigaciones de Historia Económica, 2006, 5, pp. 9-37.

Cuervo Fuente, Noemí. Población y crecimiento agrario en un territorio de la España central. La provincia de Ávila (siglos XVI-XIX). Madrid: Universidad Complutense de Madrid, 2015, tesis doctoral inédita.

Delgado Ribas, Josep María. "El modelo catalán dentro del sistema de libre comercio». En VV. AA. El comercio libre entre España y América Latina (1765-1824). Madrid: Fundación Banco Exterior, 1987, pp. 53-70.

Durán, Monserrat y FeLIU, Gaspar. «Algunos datos para el cálculo del PIB catalán (siglos XVI-XVIII), con escepticismom. Comunicación presentada a la Sesión Plenaria A del $I X$ Congreso de la AEHE. Murcia, 2008.

EIRAS ROEL, Antonio. «Dîme et mouvement du produit agricole en Galice, 1600-1837». En Goy, J. y Le Roy Ladurie, E. (eds.). Prestations paysannes, dîmes, rente foncière et mouvement de la production agricole à l'époque préindustrielle. Paris: Mouton, 1982, pp. 341-358.

Federico, Giovanni y Malanima, Paolo. «Progress, decline, growth: product and productivity in Italian agriculture, 1000-2000». Economic History Review, 2004, LVII, 3, pp. 437-464.

Feliu Monfort, Gaspar. Precios y salarios en la Cataluña moderna, vols. I y II. Madrid: Servicio de Estudios del Banco de España, 1991.

Feliu Monfort, Gaspar. "Aproximació a un índex del cost de la vida a Barcelona, 15011807». En Fontana, J. (ed.). Història i projecte social. Reconeixement a una trajèctoria, I. Barcelona: Crítica, 2004, pp. 151-170. 
FERnÁNDEZ De Pinedo, Emiliano. Crecimiento económico y transformaciones sociales del País Vasco (1100-1850). Madrid: Siglo XXI, 1974.

FERnÁNDEZ DE PINEDO, Emiliano y GarCía-ZÚÑIGa, Mario. "Evolución de las macromagnitudes económicas en el País Vasco, 1640-1780. Un ensayo». Comunicación presentada al IX Congreso de la AEHE. Murcia, 2008.

FERnÁNDEZ Díaz, Roberto. Carlos III. Un monarca reformista. Barcelona: Espasa, 2016.

FERRER I ALÒS, Llorenç. «Una revisió del creixement demogràfic de Catalunya en el segle XVIII a partir dels registres parroquials». Estudis d'Història Agrària, 2007, 20, pp. 17-68.

ForTEA PÉREZ, José Ignacio. Córdoba en el siglo XVI. Las bases demográficas y económicas de una expansión urbana. Córdoba: Monte de Piedad y Caja de Ahorros de Córdoba, 1980.

Franch BenaVENT, Ricardo. Crecimiento comercial y enriquecimiento burgués en la Valencia del siglo XVIII. Valencia: Institució Alfons el Magnánim, 1986.

FRANCH BENAVENT, Ricardo. "La producción de seda en el País Valenciano durante el siglo XVIII». Noticiario de Historia Agraria, 1994, 8, pp. 67-98.

FRANCH BENAVENT, Ricardo. La sedería valenciana y el reformismo borbónico. Valencia: Institució Alfons el Magnánim, 2000.

Freire Costa, Leonor; Palma, Nuno y ReIs, Jaime. «The Great Escape? The Contribution of the Empire to Portugal's Economic Growth, 1500-1800». Working Papers in Economic History, WP 13-07. Instituto Figuerola, Universidad Carlos III de Madrid, 2013.

García MonTero, Héctor. «Los niveles de vida en la España del Antiguo Régimen. Estado de la cuestión y propuestas de investigación». En Chastagnaret, G.; Daumas, J. C.; EscuDero, A. y Raveaux, O. (eds.). Los niveles de vida en España y Francia (siglos XVIII-XX). Alicante: Universidad de Alicante, 2010, pp. 21-44.

García Sanz, Ángel. Desarrollo y crisis del Antiguo Régimen en Castilla la Vieja. Economía $y$ sociedad en tierras de Segovia, 1500-1814. Madrid: Akal, 1977.

GARCíA SANZ, Ángel. "Crisis de la agricultura tradicional y revolución liberal (1800-1850)». En GARCÍA SANZ, Á. y GARRABOU, R. (eds.). Historia agraria de la España contemporánea. 1. Cambio social y nuevas formas de propiedad (1800-1850). Barcelona: Crítica, 1985, pp. 7-99.

GARCíA SANZ, Ángel. «El sector agrario durante el siglo XVII: depresión y reajustes». En Domínguez OrTIZ, A. (coord.). La crisis del siglo XVII: la población, la economía, la sociedad. Madrid: Espasa-Calpe, 1989, pp. 161-235.

GARCía SANZ, Ángel. "La reforma agraria de la Ilustración: proyectos y resultados. El precedente del arbitrismo agrarista castellano». En García SANZ, Á. y SANZ FERnándeZ, J. (coords.). Reformas y políticas agrarias en la historia de España. Madrid: Ministerio de Agricultura, 1996, pp. 161-200.

GiméNEZ López, Enrique. Alicante en el siglo XVIII. Economía de una ciudad portuaria en el Antiguo Régimen. Valencia: Institución Alfonso el Magnánimo, 1981.

González Agudo, David. Población, precios y renta de la tierra de Toledo, siglos XVI-XVII. Madrid: Universidad Complutense de Madrid, 2015, tesis doctoral inédita.

GonZÁlez Enciso, Agustín. Estado e industria en el siglo XVIII. La fábrica de Guadalajara. Madrid: Fundación Universitaria Española, 1980.

GonZÁlez de Molina, Manuel y Sevilla GuZmán, Eduardo. "Minifundio y gran propiedad agraria: estabilidad y cambio en la Alta Andalucía, 1758-1930». En SAAVEDRA, P. y ViLLARES, R. (eds.). Señores y campesinos en la península Ibérica, siglos XVIII-XX. Barcelona: Crítica, vol. 2, 1991, pp. 88-138. 
GONZÁlez MARISCAL, Manuel. Población, coste de la vida, producción agraria y renta de la tierra en Andalucía occidental, 1521-1800. Madrid: Universidad Complutense de Madrid, 2013, tesis doctoral inédita.

GoY, Joseph y LE Roy LADURIE, Emmanuel (eds.). Prestations paysannes, dîmes, rente foncière et mouvement de la production agricole a l'époque préindustrielle. Paris: Éditions de L'École des Hautes Études en Sciences Sociales, 1982.

Grafe, Regina. Distant Tyranny. Markets, Power and Backwardness in Spain, 1650-1800. Princeton: Princeton University Press, 2012.

Helguera, Juan y SÁnChez Sú́rez, Alejandro. "Nuevas formas de industria». En NADAl, J. y BENAUL, J. M. (coords.). «La industria en vísperas de la industrialización, 1750-2000». NADAL, J. (dir.). Atlas de la industrialización de España, 1750-2000. Barcelona: Crítica-Fundación BBVA, 2003, pp. 48-56.

HERNÁNDEZ GARCÍA, Ricardo. La manufactura lanera castellana: una herencia malbaratada, 1750-1850. Palencia: Región Editorial, 2010.

HERNÁNDEZ GARCÍA, Ricardo. «Women's labor participation rates in the kingdom of Castilla in the $18^{\text {th }}$ century». Feminist Economics, 2013a, 19 (4), pp. 181-199.

HERNÁNDEZ GARCÍA, Ricardo. "La mano de obra infantil en la Castilla rural del siglo XVIII: el trabajo del niño es poco pero el que lo desprecia, un loco». En BorRás, J. M. (ed.). El trabajo infantil en España (1750-1950). Barcelona: Icaria-Universitat de Barcelona, 2013b, pp. 91-116.

Hernández García, Ricardo y Pérez Romero, Emilio. "La evolución del producto agrario en Castilla y León durante la Edad Moderna. Problemas y posibilidades para su estimación a partir de fuentes decimales». Comunicación presentada al IX Congreso de la AEHE. Murcia, 2008.

HerR, Richard. España y la revolución del siglo XVIII. Madrid: Aguilar, 1979.

HerR, Richard. La Hacienda Real y los cambios rurales en la España de finales del Antiguo Régimen. Madrid: Instituto de Estudios Fiscales, 1991.

Hoffman, Philip T.; Jacks, David S.; Levin, Patricia A. y Lindert, Peter H. «Real inequality in Europe since 1500». The Journal of Economic History, 2002, 62, 2, pp. 322-355.

HumpHries, Jane y WeISDORF, Jacob. «Unreal wages? Real income and economic growth in England, 1260-1850». Discussion Paper DP11999, Centre for Economic Policy Research, 2017.

JOVER, Gabriel y MANERA, Carles. «Producción y productividad agrícola en la isla de Mallorca, 1590-1860». Revista de Historia Económica-Journal of Iberian and Latin American Economic History, 2009, 27, pp. 463-498.

Jover, Gabriel y MANERA, Carles. "La remuneración de la mano de obra jornalera agrícola: un ensayo de reconstrucción e interpretación a partir de los libros de cuentas del predio Raixa, Mallorca, 1717-1806». Comunicación presentada al XII Congreso de la AEHE. Salamanca, 2017.

LANZA García, Ramón. «Producto neto, gasto y crecimiento económico en el Antiguo Régimen: el caso de Cantabria». Comunicación presentada al IX Congreso de la AEHE. Murcia, 2008.

LanZa García, Ramón. Miseria, cambio y progreso en el Antiguo Régimen. Cantabria, siglos XVI-XVIII. Santander: PUbliCan, 2010.

LATORRE CiRIA, José Manuel. «La evolución del producto agrario en el sur aragonés durante la Edad Moderna». Investigaciones de Historia Económica, 2010, 18, pp. 67-102.

LÁZARO, Mercedes y GurRía, Pedro A. Las crisis de mortalidad en La Rioja (siglos XVI-XVIII). Logroño: Instituto de Estudios Riojanos, 1989. 
LLOPIS AGELÁN, Enrique. "La formación del "desierto manufacturero" extremeño: el declive de la pañería tradicional al final del Antiguo Régimen”. Revista de Historia Industrial, 1993, 3, 41-64.

Llopis Agelán, Enrique. "El legado económico del Antiguo Régimen desde la óptica regional». En Germán, L.; Llopis, E.; MaluQuer de Motes, J. y Zapata, S. (eds.). Historia económica regional de España, siglos XIX y XX. Barcelona: Crítica, 2001, pp. 507-524.

LLOPIS AgELÁN, Enrique. "Expansión, reformismo y obstáculos al crecimiento (1715-1789)». En Comín, F.; Hernández, M. y Llopis, E. (eds.). Historia económica de España. Siglos $X$-XX. Barcelona: Crítica, 2002, pp. 121-164.

LLOPIS AgELÁn, Enrique. "España, la "revolución de los modernistas" y el legado del Antiguo Régimen». En Llopis, E. (ed.). El legado económico del Antiguo Régimen en España. Barcelona: Crítica, 2004a, pp. 11-76.

Llopis Agelán, Enrique. "Campomanes, la Pragmática de 1765 y los mercados de cereales antes y después de la reforma». En Martín ACeña, P. y Comín, F. (coords.). Campomanes y su obra económica. Madrid: Instituto de Estudios Fiscales, 2004b, pp. 73-104.

Llopis AgELÁN, Enrique. «El crecimiento de la población española, 1700-1849: índices regionales y nacional de bautismos». Áreas. Revista Internacional de Ciencias Sociales, 2004c, 24, pp. 9-24.

LLOPIS Agelán, Enrique. "La crisis económica en la España del siglo XVII: la decadencia de Castilla». En VV. AA. Las crisis a lo largo de la historia. Valladolid: Universidad de Valladolid, 2010, pp. 46-96.

Llopis Agelán, Enrique. "La crisis del Antiguo Régimen, 1789-1840». En Llopis, E. y MaLuQUER DE MOTES, J. (eds.). España en crisis. Las grandes depresiones económicas, 13482012. Barcelona: Pasado \& Presente, 2013, pp. 97-132.

LLOPIS, Enrique y ABARCA, Vanesa. «El retroceso de la mortalidad catastrófica y su papel en la moderación de la mortalidad general en la España interior en los siglos XVIII-XIX». Comunicación presentada al IV CLADHE. Bogotá, 2014.

Llopis, Enrique; Alonso, Elvira; Fontanilla, Paloma; Hípola, Belén; MÉndez, Sara y Ramos, Javier. "Crecimiento económico sin mayor bienestar. Mortalidad, mortalidad catastrófica e inestabilidad demográfica y económica en Murcia, 1769-1895". Comunicación presentada al XII Congreso de la AEHE, Salamanca, 2017.

Llopis, Enrique; Bernardos, José Ubaldo y Velasco, Ángel Luis. «¿Pasó de largo por la España interior la primera fase de la transición demográfica? La mortalidad de Ávila y Guadalajara, 1700-1895”. Investigaciones de Historia Económica, 2015, 11, pp. 69-79.

Llopis, Enrique y García MONTERO, Héctor. «Precios y salarios en Madrid, 1680-1800». Investigaciones de Historia Económica, 2011, 7, 3, pp. 295-309.

LLOPIS, Enrique y GONZÁLEZ MARISCAL, Manuel. "La tasa de urbanización de España a finales del siglo XVIII. El problema de las agrociudades». En VV. AA. Miscel.lània en homenaje a Ernest Lluch. Vilassar de Mar: Fundación Ernest Lluch, 2006, pp. 351-369.

LLOPIS, Enrique y GONZÁLEZ MARISCAL, Manuel. «Un crecimiento tempranamente quebrado: el producto agrario en Andalucía occidental en la Edad Moderna». Historia Agraria, 2010, 50, pp. 13-42.

Llopis, Enrique y PÉREz MoredA, Vicente. «Evolución demográfica de la zona centro de España a través de los índices de bautismos, 1580-1850». En VV. AA. Estudios de Historia y Pensamiento Económico. Homenaje al Profesor Francisco Bustelo García del Real. Madrid: Editorial Complutense, 2003, pp. 113-146. 
Llopis, Enrique; PÉREZ Moreda, Vicente y SEBASTián, José Antonio. «Algunas sombras en el Siglo de las Luces. La sobremortalidad adulta en el interior castellano a mediados del Setecientos». En García Ruiz, J. L. y Ortiz-Villajos, J. M. (eds.). Ensayos de Historia y Pensamiento Económicos, en homenaje al Prof. Juan Hernández Andreu. Madrid: Delta Publicaciones, 2015, pp. 69-82.

Llopis, Enrique y SÁnchez SAlazar, Felipa. "The crisis of 1803-1805 in the two Castile: foodstuff, mortality and institutional collapse». Revista de Historia Económica-Journal of Iberian and Latin American History, 2016, 34, 2, pp. 295-322.

Llopis, Enrique y SEBASTián, José Antonio. «La economía española del Antiguo Régimen. Balance y legado». En Dobado, R.; Gómez-Galvarriato, A. y Márquez, G. (comps.). México y España ¿Historias económicas paralelas? México DF: Fondo de Cultura Económica, 2007, pp. 77-135.

Llopis, Enrique; Sebastián, José Antonio; Abarca, Vanesa; Bernardos, José Ubaldo y Velas$\mathrm{CO}$, Ángel Luis. ¿Retrocedió el producto agrario por habitante en la Europa moderna? El caso castellano. Documento de Trabajo de la Asociación Española de Historia Económica, DT-AEHE 1611, www.aehe.es, 2016, 51 pp.

Llopis, Enrique; Sebastián, José Antonio; Abarca, Vanesa; Sánchez Salazar, Felipa y VeLASCO, Ángel Luis. «La mortalidad cerca de una gran ciudad: el mundo rural madrileño en los siglos XVIII y XIX». Comunicación presentada al XII Congreso de la AEHE. Salamanca, 2017.

Llopis, Enrique; Sebastián, José Antonio; Bernardos, José Ubaldo; Velasco, Ángel Luis y ABARCA, Vanesa "¿Descendió el producto agrario por habitante en la Europa moderna? El caso castellano». Investigaciones de Historia Económica, 2018, 14, 2, pp. 69-81.

LLopis, Enrique y SoTOCA, Sonia. «La integración del mercado español del trigo en los siglos XVIII y XIX: un proceso precoz, prolongado y agitadom. Comunicación presentada al VIII Congreso de la AEHE. Santiago de Compostela, 2005.

López BARAHONA, Victoria. Las trabajadoras en la sociedad madrileña del siglo XVIII. Madrid: ACCI \& Libros del Taller de Historia, 2016.

LÓPEZ García, José Miguel. El motín contra Esquilache. Madrid: Alianza, 2006.

LóPez Losa, Ernesto y PIQuero, Santiago. Spanish real wages in the Northern-Western European mirror, 1500-1800. On the timings and magnitude of the Little Divergence in Europe. Documento de Trabajo de la Asociación Española de Historia Económica, DT-AEHE 1607, www.aehe.es, 2016, 43 páginas.

López SALAZAR, Jerónimo y MarTín GaLÁn, Manuel. «La producción cerealista del Arzobispado de Toledo, 1463-1699". Cuadernos de Historia Moderna y Contemporánea, 1981, vol. II, pp. 56-101.

Madrazo Madrazo, Santos. El sistema de comunicaciones en España, 1750-1850. 2 vols. Madrid: Turner, 1984.

Malanima, Paolo. "Measuring the Italian Economy. 1300-1861". Revista di Storia Economica, 2003, XIX, pp. 265-295.

Malanima, Paolo. "An Age of Decline. Product and Income in Eighteenth-Nineteenth Century Italy". Revista di Storia Economica, 2006, XXI, pp. 91-133.

Malanima, Paolo. Pre-Modern European Economy. One thousand years (10th-19th centuries). Leiden-Boston: Brill, 2009.

Malanima, Paolo. «The Long Decline of a Leading Economy: GPD in Central and Northern Italy, 1300-1913". European Review of Economic History, 2011, 15, pp. 169-219. 
Manera Erbina, Carles. Història del creixement econòmic a Mallorca (1700-2000). Palma de Mallorca: Lleonard Muntaner Editor, 2001.

MARCos MARTín, Alberto. «El crecimiento agrario castellano del siglo XVIII en el movimiento de larga duración: ¿mito o realidad?». En VV. AA. Estructuras agrarias y reformismo ilustrado en la España del siglo XVIII. Madrid: Ministerio de Agricultura, 1989, pp. 133-163.

Marcos MarTín, Alberto. España en los siglos XVI, XVII y XVIII. Economía y sociedad. Barcelona: Crítica/Caja Duero, 2000.

MARICHAL SALINAS, Carlos. "Beneficios y costes fiscales del colonialismo: las remesas americanas a España, 1760-1814». Revista de Historia Económica-Journal of Iberian and Latin American Economic History, 1997, XV, 3, pp. 475-506.

Mateu TorTosa, Enric. Arroz y paludismo. Riqueza y conflicto en la sociedad valenciana del siglo XVIII. Valencia: Institución Alfonso el Magnánimo, 1987.

Melón Jiménez, Miguel Ángel. Extremadura en el Antiguo Régimen: Economía y Sociedad en tierras de Cáceres, 1700-1814. Mérida: Editora Regional de Extremadura, 1989.

Moll, Isabel; Segura, Antoni y SuAu, Jaume. Cronología de les crises demogràfiques a MaIlorca, segles XVIII-XIX. Palma de Mallorca: Institut d'Estudis Balearics, 1983.

MORENO LÁZARO, Javier. La industria harinera en Castilla la Vieja y León, 1778-1913. Valladolid: Universidad de Valladolid, 1997, tesis doctoral inédita.

MoRenO LÁZARO, Javier. "¿Fomentó el capitalismo agrario la desigualdad? Salarios y niveles de vida en Castilla la Vieja, 1751-1861». En Martínez CARrión, J. M. (ed.). El nivel de vida en la España rural, siglos XVIII-XX. Salamanca: Publicaciones de la Universidad de Alicante, 2002, pp. 75-112.

MOREY Tous, Antònia. «La especialización económica de las Baleares desde la crisis bajomedieval hasta la etapa final del Antiguo Régimen». En VV. AA. Economía e insularidad (siglos XIV-XX). La Laguna: Universidad de La Laguna, vol. 1, 2007, pp. 289-320.

NADAL, Jordi y BENAUL, Josep María (coords.). «La industria en vísperas de la industrialización, 1750-2000». En NADAL, J. (dir.). Atlas de la industrialización de España, 17502000. Barcelona: Crítica-Fundación BBVA, 2003, pp. 25-56.

Palma, Nuno y ReIs, Jaime. "Portuguese demography and economic growth, 1500-1850». Prepared for the Accounting for the Great Divergence Conference. The University of Warwick in Venice, 2014, 22-24 May.

Palma, Nuno y ReIs, Jaime. «From convergence to divergence: Portuguese demography and economic growth, 1500-1850». Memorandum 161, Groningen Growth and Development Center. University of Groningen, 2016.

Palop Ramos, José Miguel. Hambre y lucha antifeudal. Las crisis de subsistencias en Valencia (siglo XVIII). Madrid: Siglo XXI, 1977.

PANTA, Luigi del y LIVI-BACCI, Massimo. "Chronologie, intensité et diffusion des crises de mortalité en Italie: 1600-1850». Population, número spécial, 1977, pp. 401-446.

Parejo Barranco, José Antonio. Industria dispersa e industrialización en Andalucía: el textil antequerano, 1750-1900. Málaga: Universidad de Málaga, 1987.

PÉREZ MoredA, Vicente. Las crisis de mortalidad en la España interior, siglos XVI-XIX. Madrid: Siglo XXI, 1980.

PÉREZ MOREDA, Vicente. "Crisis demográficas y crisis agrarias: paludismo y agricultura en España a fines del siglo XVIII. En VV. AA. Congreso de Historia Rural. Siglos XV al XIX. Madrid: Universidad Complutense de Madrid, 1984, pp. 333-354. 
Pérez PicAzo, María Teresa. "Crecimiento agrícola y relaciones de mercado en el reino de Murcia durante el siglo XVIII. En VV. AA. Estructuras agrarias y reformismo ilustrado en la España del siglo XVIII. Madrid: Ministerio de Agricultura, 1989, pp. 47-61.

Pérez Romero, Emilio. «Un mundo inmóvil: el producto agrícola por habitante en la cuenca alta del Duero durante la Edad Moderna». Investigaciones de Historia Económica, 2009, 14, pp. 69-102.

PÉREZ SARRIón, Guillermo. La península comercial. Mercado, redes sociales y Estado en España en el siglo XVIII. Madrid: Marcial Pons, 2012.

PERRENOUd, Alfred. «El retroceso de la mortalidad ordinaria». En BARDET, J.-P. y DuPÂQUIER, J. (dirs.). Historia de las poblaciones europeas. II. La revolución demográfica, 17501914. Madrid: Síntesis, 2001, pp. 59-82.

PFISTER, Ulrich. «Economic growth in Germany, 1500-1850». Paper to The Quantifying Long Run Economic Development Conference. University of Warwick in Venice, 2011, 22-24 March.

Piqueras Haba, Juan. La vid y el vino en el País Valenciano (geografía económica, 15641980). Valencia: Institución Alfonso el Magnánimo, 1981.

PiQuero, Santiago. Demografía guipuzcoana en el Antiguo Régimen. Bilbao: Universidad del País Vasco, 1991.

ReHER, David S. y BALLeSTERos, Esmeralda. «Precios y salarios en Castilla la Nueva: la construcción de un índice de salarios reales, 1501-1991». Revista de Historia EconómicaJournal of Iberian and Latin American Economic History, 1993, XI, pp. 101-151.

REIS, Jaime. "Gross agricultural output: a quantitative, unified perspective, 1500-1850». En Freire, D. y LAINS, P. (eds.). An agrarian history of Portugal, 1000-2000: economic development on the European frontier. Leiden \& Boston: Brill, 2017, pp. 172-216.

Ringrose, David R. España, 1700-1900: el mito del fracaso. Madrid: Alianza Editorial, 1996.

Ros Massana, Rosa. La industria textil lanera de Béjar (1680-1850): la formación de un enclave industrial. Salamanca: Junta de Castilla y León, 1999.

RuBIo PÉREZ, Laureano. La burguesía maragata: dimensión social, comercio y capital en la Corona de Castilla durante la Edad Moderna. León: Universidad de León, 1995.

Ruiz TORRes, Pedro. Reformismo e Ilustración. En Fontana, J. y Villares, R. (dirs.). Historia de España, volumen V. Madrid: Crítica-Marcial Pons, 2008.

SaAvedra Fernández, Pegerto. Economía, Política y Sociedad en Galicia: La provincia de Mondoñedo, 1480-1830. Madrid: Xunta de Galicia, 1985.

SaAvedra Fernández, Pegerto. Galicia. Historia. III: La Galicia del Antiguo Régimen. Economía y sociedad. La Coruña: Hércules de Ediciones, 1991.

SÁNCHEZ SAlAZAR, Felipa. Extensión de cultivos en España en el siglo XVIII. Roturas y repartos de tierras concejiles. Madrid: Siglo XXI, 1988.

SARASÚA, Carmen. Criados, nodrizas y amos. El servicio doméstico en la formación del mercado de trabajo madrileño, 1758-1868. Madrid: Siglo XxI, 1994.

SARASÚA, Carmen. "Working Harder but Still Poor. The "Industrious Revolution" in 18th Century Spain". En Xvth World Economic History Congress, session "Industrious Women and Children of the World? J. de VRIES "Industrious Revolution" as a Conceptual Tool for Researching Women's and Children's Work in an International Perspective», 2009, Utrecht, 2009.

SARASÚA, Carmen. ¿Activos desde cuándo? La edad de acceso al mercado de trabajo en la España del siglo XVIII. Documento de Trabajo de la Asociación Española de Historia Económica, DT-AEHE 1309, www.aehe.es, 2013, 26 páginas. 
SARASÚA, Carmen. "Women's work and structural change: occupational structure in eighteenth-century Spain». Economic History Review, 2018, https://onlinelibrary.wiley. com/doi/abs/10.1111/ehr.12733.

SCHOFIELD, Roger y ReHER, David S. "The decline of mortality in Europe». En SCHOfIELD, R.; Reher, D. y Bideau, A. (eds.). The Decline of Mortality in Europe. Oxford: Oxford University Press, 1991, pp. 1-17.

SCHÖN, Lennart y KranTZ, Olle. "The Swedish economy in the early modern period: constructing historical national accounts». European Review of Economic History, 2012, 16, pp. 529-549.

Sebastián Amarilla, José Antonio. «La renta de la tierra en León durante la Edad Moderna. Primeros resultados y algunas reflexiones a partir de fuentes monásticas». Revista de Historia Económica-Journal of Iberian and Latin American Economic History, 1990, VIII, 1, pp. 53-80.

SEBASTIÁN AMARILLA, José Antonio. "La producción de cereales en tierras de León en la Edad Moderna, 1570-1795". Agricultura y Sociedad, 1991, 59, pp. 75-118.

Sebastián Amarilla, José Antonio. Agricultura y rentas monásticas en tierras de León. Santa María de Sandoval (1167-1835). 2 vols. Madrid: Universidad Complutense de Madrid, 1992.

SEBASTIÁn AMARILLA, José Antonio. «La agricultura española y el legado del Antiguo Régimen (1780-1855)». En Llopis, E. (ed.). El legado económico del Antiguo Régimen en España. Barcelona: Crítica, 2004, pp. 147-186.

Sebastián Amarilla, José Antonio. «El largo siglo XVII: crisis en España, depresión en Castilla». En Llopis, E. y MALuQuer De Motes, J. (eds.). España en crisis. Las grandes depresiones económicas, 1348-2012. Barcelona: Pasado \& Presente, 2013, pp. 59-96.

Sebastián, José Antonio; García Montero, Héctor; Bernardos, José Ubaldo y ZaFra, Juan. "Del crecimiento a la decepción. La producción agraria en Castilla-La Mancha en la Edad Moderna, una primera aproximación». Comunicación presentada al IX Congreso de la AEHE. Murcia, 2008.

SERRÃO, José Vicente. "A agricultura portuguesa no século XVIII: ¿progresso ou atraso?». En MоттA, M. (org.). Terras lusas: a questão agraria em Portugal. Rio de Janeiro: Editora da UFF, 2007, pp. 31-70.

SERrão, José Vicente. "Extensive growth and market expansion». En Freire, D. y LaINS, P. (eds.). An agrarian history of Portugal, 1000-2000: economic development on the European frontier. Leiden \& Boston: Brill, 2017, pp. 132-170.

Tello ARAgaY, Enric. "Renta señorial y renta de la tierra en la última etapa del Antiguo Régimen en Cataluña». Noticiario de Historia Agraria, 1992, 2, 4, pp. 283-314.

Tello AragaY, Enric. "El fin de la expansión agraria en la Cataluña del siglo XVIII: factores económicos y crisis social». Agricultura y Sociedad, 1995, 74, pp. 109-158.

Tinoco, Santiago y Fradera, Josep María. "A modo de primeras conclusiones». En VV. AA. El comercio libre entre España y América Latina (1765-1824). Madrid: Fundación Banco Exterior, 1987, pp. 317-324.

TORRAS ElíAs, Jaume. "L'economia catalana abans del 1800. Un esquema». En VV. AA. Història econòmica de la Catalunya contemporània, s. XIX. 1. La formació d'una societat industrial. Barcelona: Enciclopedia Catalana, 1994, pp. 13-38.

TORras Elías, Jaume. Fabricants sense fàbrica. Els Torelló, d'Igualada (1691-1794). Vic: Eumo, 2007. 
TORRó GIL, Lluís. Proto-industria i acumulació originaria de capital a la vila valenciana d'Alcoi (1430-1823). Alicante: Universidad de Alicante, 2000.

VALLIN, Jacques. «Mortality in Europe from 1720 to 1914: Long-term trends and changes in patterns by age and sex». En Schofield, R.; Reher, D. y Bideau, A. (eds.). The Decline of Mortality in Europe. Oxford: Oxford University Press, 1991, pp. 38-67.

VAlls Junyent, Francesc. La dinàmica del canvi agrari a Catalunya. L'Anoia, 1720-1860. Barcelona: Abadía de Montserrat, 1996.

Valls Junyent, Francesc. La Catalunya atlántica. Aiguardent i teixits a l'arrencada industrial catalana. Barcelona: Eumo y Universitat de Vic, 2004.

VILAR, Pierre. Cataluña en la España moderna, tomo I. Barcelona: Crítica, 1978.

VOTH, Hans-Joachim. "Time and work in Eighteenth-Century London". The Journal of Economic History, 1998, 58, pp. 29-58.

VRIES, Jan de. "The Industrial Revolution and the Industrious Revolution». The Journal of Economic History, 1994, 54, 2, pp. 249-270.

VRIES, Jan de. La revolución industriosa. Consumo y economía doméstica desde 1650 hasta el presente. Barcelona: Crítica, 2009.

Yun, Bartolomé. «Del centro a la periferia: la economía castellana bajo Carlos II». Studia Historica. Historia Moderna, 1999, 20, pp. 45-76.

ZANDEN, Jan Luiten van y LEEUweN, Bas van. «Persistent but not consistent: the growth of national income in Holland, 1347-1807». Explorations in Economic History, 2012, 49, pp. 119-130. 
